\title{
Effect of co-firing coal and biomass blends on the gaseous environments and ash deposition during pilot-scale oxy-combustion trials
}

\author{
N. Jurado ${ }^{\text {a }}$, N.J. Simms ${ }^{\text {b }}$, E. J. Anthony ${ }^{\text {a }}$, J. E. Oakey ${ }^{\text {b* }}$ \\ ${ }^{a}$ Centre for Combustion, Carbon Capture and Storage, Cranfield University, Cranfield, Bedfordshire MK43 OAL, UK \\ ${ }^{b}$ Centre for Power Engineering, Cranfield University, Cranfield, Bedfordshire MK43 OAL, UK \\ * Corresponding author. E-mail address: J.E.Oakey@cranfield.ac.uk (J. E. Oakey).
}

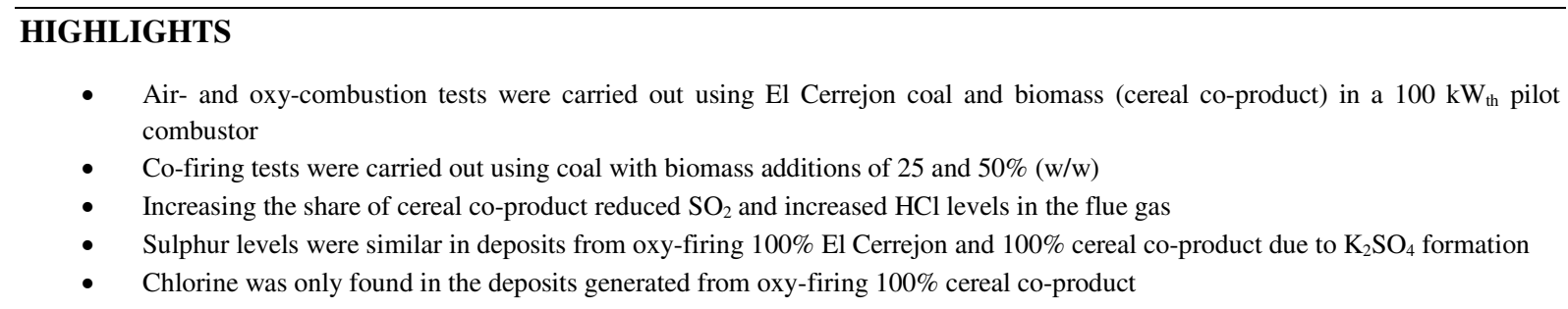

\begin{abstract}
This paper presents the experimental results from co-firing blends of El Cerrejon (EC) coal and cereal co-product (CCP) using several ratios $(100 / 0 ; 75 / 25 ; 50 / 50 ; 0 / 100(\mathrm{w} / \mathrm{w}))$ under air- and oxy-firing conditions, in a retrofitted $100 \mathrm{~kW}$ th pulverised fuel combustor. An on-line high-resolution multi-component Fourier Transform Infra-red (FTIR) analyser was used to measure $\mathrm{CO}_{2}, \mathrm{O}_{2}, \mathrm{H}_{2} \mathrm{O}, \mathrm{CO}_{1} \mathrm{NO}_{2} \mathrm{NO}_{2}, \mathrm{~N}_{2} \mathrm{O}$, $\mathrm{NH}_{3}, \mathrm{SO}_{2}, \mathrm{HCl}, \mathrm{HF}$ and $\mathrm{CH}_{4}$. A comprehensive evaluation of the major and minor species present in the flue gas was carried out to study the effects of the addition of biomass, the firing mode (air/oxy) and the type of recycle (wet/dry) on the gaseous environment in the combustor. It was found that similar $\mathrm{CO}_{2}$ levels can be reached when using pure coal or pure biomass, on a dry basis. For the minor species, the increase in the share of biomass had the effect of decreasing the $\mathrm{SO}_{2}$ levels reached in the flue gas and increasing the $\mathrm{HCl}$ content. No significant variation in the $\mathrm{NO}_{\mathrm{x}}$ levels was observed as a consequence of using high percentages of biomass. For ash deposit characterisation, two probes were used for which surface temperatures were controlled at $650^{\circ}$ and $750^{\circ} \mathrm{C}$. Environmental scanning electron microscopy (ESEM) with energy dispersive X-ray (EDX) analysis, supported by X-ray diffraction (XRD), were used to study the deposits. The ESEM/EDX and XRD results showed similar sulphur levels in the deposits when varying the share of biomass even though EC coal contains 3.5 times more sulphur than CCP. This is thought to be a consequence of the reaction of sulphur with the alkalis, especially potassium, present at higher levels in the $\mathrm{CCP}$, which produces higher levels of $\mathrm{K}_{2} \mathrm{SO}_{4}$ in the combustion gas. Chlorine was only found in the deposits generated using pure CCP under oxy-firing conditions. An evaluation of the different mineral species formed when varying the biomass share and the firing mode was also performed. Results obtained comparing the mineral species in deposits when using 100\% CCP, switching from air to oxyfiring conditions, showed that in air-firing $\mathrm{CCP}$ deposits had higher levels of aluminium phosphate and arcanite $\left(\mathrm{K}_{2} \mathrm{SO}_{4}\right)$. $\mathrm{Also}$, under oxyfiring conditions, $100 \%$ CCP-derived deposits had a higher level of potassium magnesium chloride compared $100 \%$ EC.
\end{abstract}

Keywords:

Oxy-fuel

Co-firing

Coal combustion

Biomass

Ash deposition

Alkali sulphates

\section{Introduction}

The production of energy represents the largest contribution to anthropogenic greenhouse gas emissions, accounting for $83 \%$ of the total, followed by agriculture (8\%), industrial processes (6\%), and waste (3\%) [1]. Figures reported in 2013[1] by the International Energy Agency (IEA) showed that although coal represented $29 \%$ of the primary energy supply, the use of coal was responsible for the highest fraction of the global $\mathrm{CO}_{2}$ emissions (44\%), followed by oil (35\%), and gas (20\%); only $1 \%$ of the share of $\mathrm{CO}_{2}$ emissions was due to the use of carbon-neutral fuels, where nuclear, hydro, geothermal, solar, tide, wind, biofuels and waste are included. Coal is the highest contributor to $\mathrm{CO}_{2}$ emissions because of its high content of carbon per unit of energy released, and the fact that energy 
from carbon-neutral fuels accounted for only $18 \%$ of energy production in 2011 . These figures together with the UK target to reduce its carbon emissions by $80 \%$ from 1990 levels by 2050 [2], and the need for flexible power, mean that carbon capture and storage (CCS) technologies and biofuels must play an important role to achieve the goals set by 2050 in UK.

The CCS option studied here is based on oxy-combustion. In this technology, the fuel is fired in an oxygenenriched environment with a reduced level of $\mathrm{N}_{2}$ to generate a flue gas with high concentration of $\mathrm{CO}_{2}$. Part of the flue gas is recirculated to the combustor to replace the air-derived $\mathrm{N}_{2}$ missing in oxy-firing and control flame temperature. The exhaust gas exiting the process needs a less energy intensive treatment, in comparison to other post-combustion technologies, to reach the $\mathrm{CO}_{2}$ purity needed to be storage ready. The compression and purification unit (CPU) operates downstream of the typical gas treatment required in air-firing combustion (deNOx, deSOx and ESP), and consists of the further purification of the $\mathrm{CO}_{2}$ stream, during and after compression. The supercritical fluid phase product stream from the CPU, typically has a $\mathrm{CO}_{2}$ purity of $95 \%$ (v/v) or higher [3]. Despite the promise of oxycombustion with coal and biomass co-firing, improved understanding of the environment inside the oxy-combustor, heat transfer, characteristics of the ash deposits or materials corrosion behaviour is still required through further study.

The use of biomass for co-combustion requires the evaluation of its composition and properties, as well as the assessment of industrial and environmental implications of co-firing it with coal [4]. Vassilev et al. [4] highlighted the importance of characterising biomass in terms of its: (i) chemical composition (i.e., major and minor substance as well as trace elements); (ii) mineral composition, considering organic matter (e.g., cellulose, hemicellulose, lignin, char, etc.), and inorganic matter; and (iii) other properties (i.e., volatile matter, fixed carbon, moisture, ash content, ash-fusion and combustion temperatures, density, $\mathrm{pH}$, calorific value, etc.). Unfortunately in many cases such information is not available; however, it is known that:

- Char reactivity is higher when using biomass in comparison with that of coal and biomass has a higher volatile content. This allows ignition of the char to be achieved at lower temperatures, and so less power is required for start-up of the combustion of the fuel. Namely, decreasing ignition temperatures have been seen with increasing share of biomass in the fuel mix under oxy-firing conditions $[5,6]$.

- Burnout. The degree of burnout might be expected to be enhanced for coal/biomass blends due to the higher volatile content of the biomass; however, Arias et al. [5] suggested that this increase is almost negligible. Other studies have shown that burnout when co-firing is improved by the use of biomass, and have suggested this to be a consequence of two effects: (i) the higher volatile content and reactivity of the biomass-derived char as mentioned above, and (ii) higher oxygen content in biomass, which increases the char oxidation rate [7].

- Heat flux. A few studies have been carried out on the effect on the heat transfer due to the change in the environment composition inside the reactor when oxy-firing coal and/or biomass [7,8]. Smart et al. [7] suggested that even though peak radiative and convective heat fluxes similar to the air-firing case can be obtained under oxy-firing conditions using coal or coal/biomass blends, they do not occur at the same operating conditions (e.g., flue gas recycle ratio), or at the same location (i.e., distance from the burner), because they are fuel dependent. The industrial implication of this can be that optimal operation cannot be reached for retrofitted plants as the superheaters and reheaters would be characterised based on a coalbased design; and that for new-build plants it may be necessary to redesign the superheaters and reheaters.

Regarding the environmental challenges of using biomass as fuel for power generation, both positive and negative aspects reported [4], highlighting that a complete biomass life cycle assessment is a very important tool, necessary to conduct a proper evaluation of its use. Consequently, it is advised that the biofuels employed should be classifiedas to whether they are sustainable or represent unsustainable management resources, to avoid serious environmental problems [4].

One important characteristic of the ash generated under oxy-combustion conditions is the higher likelihood that corrosion problems will appear in the boiler when fuels with medium and high content of $\mathrm{S}, \mathrm{Cl}$, and $\mathrm{F}$ are used, because of the changed environment arising from flue gas recycle. This recycle leads to the accumulation of these species inside the combustor. This, combined with greater sulphur oxides retention in fly ash when burning blends of coal and biomass, due to higher alkali content in biomass [6,9-13], can cause an increased risk of corrosion as reported by Syed et al. [9]. In their paper, it was concluded that more corrosion damage occurs under oxy-firing conditions of coal and biomass blends in comparison to air-firing combustion. The propensity to form ash deposits, as well as slagging and fouling issues related to the use of biomass in thermal applications have been addressed by several authors [10-12]. Khodier and Simms [10] pointed out the influence of $\mathrm{Na}_{2} \mathrm{SO}_{4}$ in the formation of a sticky, 
adhesive layer at the onset of deposit formation when co-firing with air. However, Chen et al. [12] noted in their paper that there is a lack of literature on the behaviour of ash, mechanisms of slag layer formation and its interaction with char particles, under oxy-combustion conditions.

In this work, experimental tests were performed co-firing a South American coal, El Cerrejon (EC), and a form of processed biomass, cereal co-product (CCP), under oxy-firing conditions using a retrofitted $100 \mathrm{~kW}_{\text {th }}$ pulverised coal combustor facility at Cranfield University. Tests using air combustion were also carried out to establish the reference case. A parametric study was performed with respect to the effect of fuel variability on composition of the combustion gas and ash deposits, paying special attention to the fate of sulphur, a key component regarding corrosion. The biomass composition, specifically its alkali and alkaline earths content, has been observed to be an important factor with regard to sulphur retention in ash deposits or conveyed in the gaseous phase as alkali sulphate aerosols. The higher potential for alkali species, $\mathrm{K}$ in particular [13], to react with $\mathrm{SO}_{3}$ to form sulphates by nucleation when flue gases are cooled down to around $1150 \mathrm{~K}$, was studied by Jiménez and Ballester [14]. These authors found that when burning pure biomass or co-firing it with coke, $\mathrm{K}_{2} \mathrm{SO}_{4}$ appeared to be the only major compound in the submicron particles. Research focused on the use of biomass (pure or co-fired) to analyse the generation of alkali sulphates in conventional combustion has been done, e.g., the aforementioned work [14], or the studies carried out by Valmari [15] and Kassman et al. [16]. These studies were, for the most part, carried out by doping the biomass with $\mathrm{S}$ for the $\mathrm{K}$ (or other alkalis present) to react with it instead of with the $\mathrm{Cl}$ also present in the biomass, because $\mathrm{KCl}$ presents more corrosion problems than $\mathrm{K}_{2} \mathrm{SO}_{4}$. Other authors have measured $\mathrm{SO}_{3}$ levels [17] or quantified the release of alkali sulphates [18] when oxy-firing coal. Modelling work, using density functional theory calculations, has also been carried out by Galloway et al. [13] with regard to $\mathrm{SO}_{3}$ retention in fly ashes, specifically its tendency to form bonds to certain species, such as $\mathrm{CaO}, \mathrm{MgO}, \mathrm{Na}_{2} \mathrm{O}$ or $\mathrm{K}_{2} \mathrm{O}$, concluding that the higher binding strengths are associated to potassium. Nonetheless, little work has been published on experimental studies of alkali sulphate levels combining both options: co-firing coal and biomass under oxy-firing conditions, which is one of the main purposes of the study reported here.

\section{Experimental procedure}

\subsection{Pilot-scale combustion test facility}

The experiments were conducted in the $100 \mathrm{~kW}_{\text {th }}$ pilot-scale pulverised fuel combustion facility at Cranfield University. A schematic diagram of this facility configured for oxy-combustion is shown in Fig. 1. 


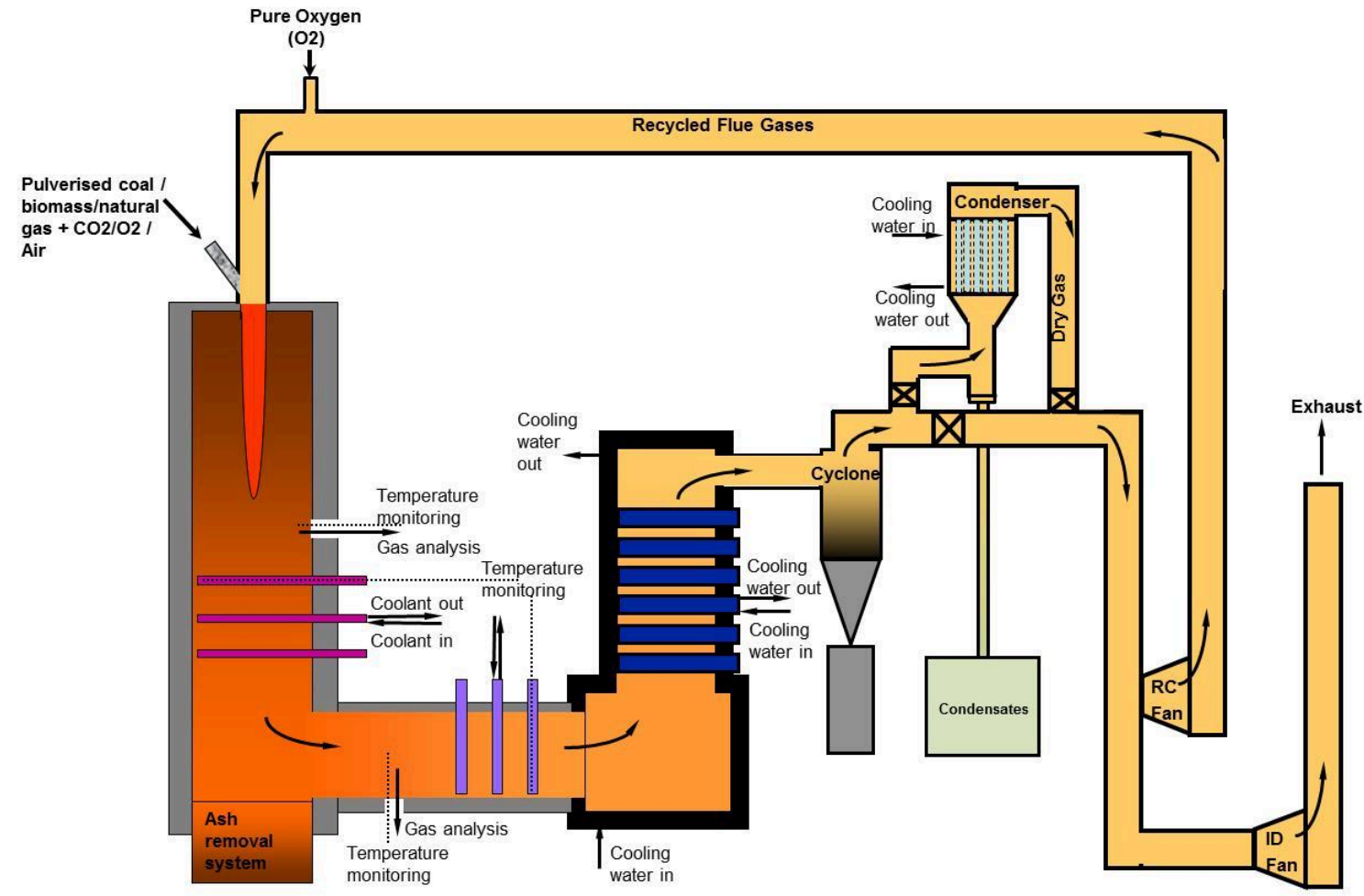

Fig. 1. Schematic diagram of the pilot-scale $\left(100 \mathrm{~kW}_{\mathrm{th}}\right)$ pulverised fuel oxy-combustion facility at Cranfield University.

The pulverised fuel was fed to the oxy-combustor at a constant rate using a fuel feeder provided by a metering screw, a vibratory tray and a venturi eductor. Additionally, the feeder has three purge points where $\mathrm{CO}_{2}$ is injected to keep a positive pressure inside the pulverised fuel feeding system so as to avoid air ingress. Once the pulverised fuel reaches the venturi eductor, it is entrained and conveyed to the burner by a stream of pure $\mathrm{CO}_{2}$ gas coming from $\mathrm{CO}_{2}$ cylinders. Prior to this stream being fed to the burner, the primary $\mathrm{O}_{2}$, coming from $\mathrm{O}_{2}$ cylinders, was injected into the stream, when using this option (primary $\mathrm{O}_{2}$ ) for a particular test. A secondary oxygen stream was used for all the oxyfiring tests, and was injected into the flue gas recycle path $1.5 \mathrm{~m}$ before its entrance to the oxy-combustor, as can be seen in Fig. 1.

The combustor was equipped with a down-fired burner, provided with a pilot flame port and a flame detector. The pulverised fuel was combusted in the vertical combustion chamber ( $3.7 \mathrm{~m}$ height) which has a square cross-section with sides of $650 \mathrm{~mm}$ surrounded by thermal insulation (175 mm thickness). The vertical combustion chamber has four view ports and ports where sensors are used to measure wall temperatures (three $\mathrm{R}$ type and three $\mathrm{K}$ type thermocouples). Three of the sampling ports, located at the bottom part of the vertical section, are used to locate 'radiant' deposition probes. To collect the deposits, it was necessary to allow the chamber to cool down for 18 to $24 \mathrm{~h}$. Then the ash deposited on the probes was sampled and analysed using ESEM/EDX and XRD techniques (see next subsection 2.2.1 for further description of ash deposit analysis). An on-line high-resolution multi-component Fourier Transform Infra-red (FTIR) analyser was used to measure $\mathrm{CO}_{2}, \mathrm{O}_{2}, \mathrm{H}_{2} \mathrm{O}, \mathrm{CO}, \mathrm{NO}, \mathrm{NO}_{2}, \mathrm{~N}_{2} \mathrm{O}, \mathrm{NH}_{3}, \mathrm{SO}_{2}, \mathrm{HCl}, \mathrm{HF}$ and $\mathrm{CH}_{4}$ (see previous work in this facility [19] for a more detailed description of this method). Special calibration spectra for 28 gas species were produced and loaded onto the FTIR sensor to measure gas emissions generated under oxycombustion conditions, as a consequence of the different ranges for concentrations expected, especially for water vapour and $\mathrm{CO}_{2}$, for which upper detection levels needed to be upgraded. The primary sampling point for the FTIR analyser was located in the vertical section of the combustor, in a port above the ones used for the ash deposit probes. A secondary FTIR sampling point was positioned after the condenser, to be able to quantify the efficiency of the condenser in removing water and soluble species.

Part of the exhaust gas was recirculated to the combustion chamber, through the recycle (RC) fan, and the remainder was sent to the stack, through the induced draft (ID) fan. The lines that convey the recycled flue gas are thermally insulated and have a trace heating system to avoid the temperature dropping below the acid dew point of the flue gas. Secondary $\mathrm{O}_{2}$ was injected into this stream prior to feeding it to the oxy-combustor. A secondary analyser, an ADC MGA 3000 Multi Gas Analyser which measures $\mathrm{CO}_{2}, \mathrm{CO}, \mathrm{O}_{2}$ and $\mathrm{SO}_{2}$, sampled the gas just before its entrance 
into the burner to monitor that the percentage of oxygen was in the range specified $(27-35 \% \mathrm{v} / \mathrm{v})$ for the oxy-firing tests.

\subsection{Ash sampling and analysis techniques}

\subsubsection{Deposit probes}

Deposit samples from the early stages of ash deposition were collected using ceramic sections mounted on metallic air-cooled probes, which were located in the lower part of the vertical section of the combustor radiant zone. These probes were placed perpendicularly to the direction of the flue gas flow. For all the tests, the nominal average surface temperatures of the probes were maintained at 650 and $750^{\circ} \mathrm{C}$, respectively, to simulate the surface temperatures reached at the superheaters/reheaters, by using cooling compressed air supplied to the internal body of the probe.

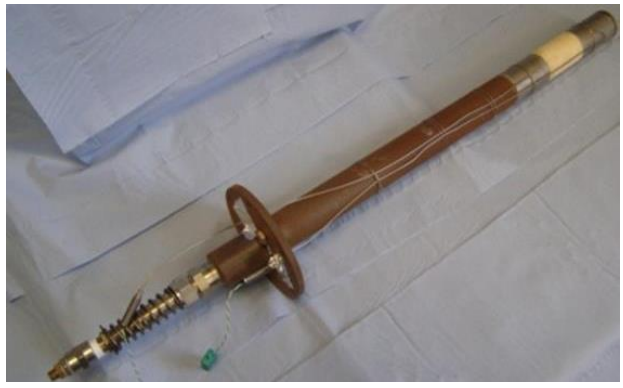

Fig. 2. Deposition probe

The compositions of the sampled deposits were analysed using two different techniques: environmental scanning electron microscopy (ESEM) with energy dispersive X-ray (EDX), and X-ray diffraction (XRD). The ESEM/EDX analysis provides information about the elements present on the surface of the sample, while XRD analysis is particularly recommended for crystalline samples, providing information about existing chemical compounds, but is less effective for amorphous materials. Most of the deposit structure is amorphous, so the main technique to evaluate the deposit composition was the ESEM/EDX. However, while most of the deposit material would be expected to be amorphous, the XRD technique was useful in characterising the crystalline compounds present in the deposits.

\subsubsection{Flyash}

As part of the studies carried out for this work, the amounts of unburnt carbon present in the fly ash samples collected from the oxy-combustion process were evaluated. Fly ash was collected from two locations: the horizontal section of the combustor and the cyclone. For the evaluation of unburnt carbon in ash, the loss on ignition (LOI) method can be applied [20]; although some studies [21] have suggested that the results for remaining char content using the LOI technique should be analysed with caution when evaluating fly ash enriched in calcium at temperatures above $500^{\circ} \mathrm{C}$, and that the use of additional techniques is advised for such cases. For the LOI method, the LOI at $550^{\circ} \mathrm{C}$ (LOI550) is related to the organic carbon content of the sample, and the LOI at $950^{\circ} \mathrm{C}$ is associated with the inorganic carbon content according to Santisteban et al. [20]. Other studies [22,23] have demonstrated that the LOI method overestimates the unburnt carbon for coal and biomass ash, respectively, when there are volatile compounds ,organic or inorganic, that can contribute to the weight loss measured during the analysis, but which are not related to residual carbon present in the sample. In the study carried out by Fan and Brown [22], where coal was used, the authors reported an overestimation around 20\%. Zhao et al. [23] studied the characteristics of ash generated from burning biomass, stating that the positive bias given by LOI550 is due to the effect of release of VOCs in the ash, and also, because at the ashing temperature, a small amount of carbonates may decompose, contributing to the weight loss. The presence of carbonates in the fly ash generated under oxy-firing conditions has been suggested by Wigley [24] to be a consequence of the inhibited decomposition of carbonates, present as minerals in the original fuel, at the high partial pressures of $\mathrm{CO}_{2}$ in the oxy-combustion environment. Zhao et al. [23] suggested measuring the carbon in ash by thermogravimetric analysis (TGA). In addition to these techniques, which belong to the ashing procedures, there is a wide range of methods that can be applied to study the organic and inorganic matter present in fly ash, according to Vassilev et al. [21]. These procedures can be classified into: (i) ashing procedures (i.e., high and low-temperature ashing); (ii) physical separation (e.g., by density, by size, magnetically, electrostatically, etc.); (iii) chemical leaching (i.e., dissolution of organic/inorganic matter, sequential leaching); (iv) sequential physical and chemical separations. 
The selection of the method(s) to evaluate the organic and inorganic matter of the fly ash will depend on several factors, such as: accuracy required of the analyses results, resources available (i.e., accessibility to equipment or qualified personnel, time availability), etc.

The technique used here to measure the carbon content of the fly ash for this work was a modification of TGA using consecutive inert and oxidising atmospheres and based on the literature this seems to be an adequate method $[22,23]$. In the variation used for the present work, the sample's weight is not measured during the process, but rather at the beginning, after passing one hour in an inert-atmosphere $\left(\mathrm{N}_{2}\right)$ furnace at $750^{\circ} \mathrm{C}$, and after passing one hour in an oxidizing-atmosphere (air) furnace at $750^{\circ} \mathrm{C}$. In the first stage, the sample is heated in an inert atmosphere $\left(\mathrm{N}_{2}\right)$, liberating the volatile matter. Then, the ash is exposed to an oxidising atmosphere, to cause the unburnt char carbon to react. The weight of the sample is recorded during the entire TGA experiment, producing a curve similar to the one shown in Fig. 3, where UC denotes unburnt carbon, and TL denotes total loss.

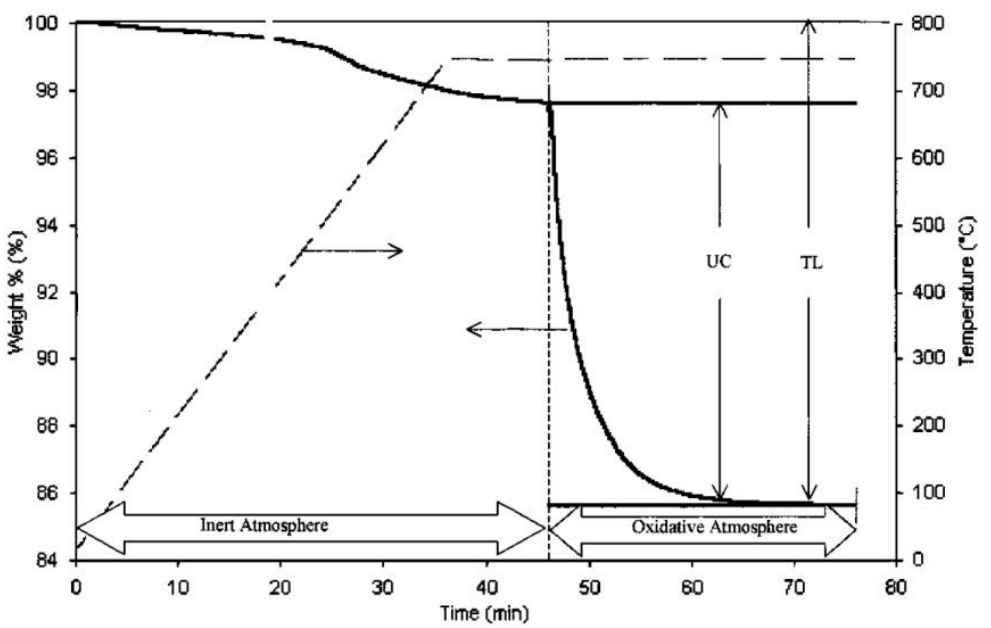

Fig. 3. TGA weight loss curve of a typical fly ash sample. Image taken from Fan and Brown [22]

\subsection{Fuels}

The fuels used for this study, EC and CCP, were supplied by E.ON New Build and Technology Ltd. (Power Technology Centre, Ratcliffe-on-Soar, Nottingham, UK) to the OxyCAP-UK consortium, funded by UK Engineering and Physical Sciences Research Council (EPSRC) where all the academic partners, Cranfield University amongst them, were studying the same fuels in order to generate comparable results. Both fuels were supplied in a pulverised form. The CCP used for this work is a blend of agricultural sub-products, produced from wheat, and straw briquettes. To avoid problems related to blockages in the eductor in the fuel feeding system, biomass was sieved before each test using a $2 \mathrm{~mm}$ mesh size, which gave an average particle size of $0.5 \mathrm{~mm}$. Constant pulverised fuel flowrates of $13.5,15,16.7$ and $22 \mathrm{~kg} / \mathrm{h}$ were supplied to the oxy-combustor with CCP additions of $0,25,50$, and $100 \%(\mathrm{w} / \mathrm{w})$, respectively.

Table 1 shows the proximate, ultimate and ash analyses of the fuels used for this study. The higher content of moisture and volatile matter of the CCP, as well as the higher levels of oxygen, hydrogen, nitrogen and chlorine in comparison to the levels presented for EC can be seen. By contrast, EC coal presents a higher level of ash in its proximate analysis and considerably higher calorific value than $\mathrm{CCP}$. Also noteworthy are the high levels of $\mathrm{K}_{2} \mathrm{O}$ and $\mathrm{P}_{2} \mathrm{O}_{5}$ in the $\mathrm{CCP}$ ash analysis. 
Table 1. Proximate, ultimate, mineral and ash analyses of the fuels.

\begin{tabular}{|c|c|c|}
\hline & El Cerrejon coal & Cereal co-product \\
\hline \multicolumn{3}{|c|}{ Proximate analysis $(\%(w / w)$ as received $)$} \\
\hline Moisture & 5.80 & 8.10 \\
\hline Volatile matter & 34.80 & 70.80 \\
\hline Ash & 8.60 & 4.20 \\
\hline \multicolumn{3}{|l|}{ Calorific value, $(\mathrm{MJ} / \mathrm{kg})$} \\
\hline Gross calorific value & 27.85 & 17.61 \\
\hline Net calorific value & 27.12 & 16.34 \\
\hline \multicolumn{3}{|c|}{ Ultimate analysis (\% (w/w) as received) } \\
\hline Carbon & 69.2 & 43.30 \\
\hline Hydrogen & 4.40 & 5.80 \\
\hline Nitrogen & 1.42 & 2.70 \\
\hline Chlorine & 0.02 & 0.17 \\
\hline Sulphur & 0.58 & 0.16 \\
\hline Oxygen & 9.98 & 35.57 \\
\hline \multicolumn{3}{|l|}{ Mineral analysis $(\%(w t))$} \\
\hline Kaolinite $\mathrm{Al}_{4} \mathrm{Si}_{4} \mathrm{O}_{10}(\mathrm{OH})_{8}$ & 16.80 & - \\
\hline Illite $\mathrm{KAl}_{2}(\mathrm{OH})_{2}\left(\mathrm{AlSi}_{3} \mathrm{O}_{10}\right)$ & 9.40 & - \\
\hline Pyrite $\mathrm{FeS}_{2}$ & 12.90 & - \\
\hline Quartz $\mathrm{SiO}_{2}$ & 54.20 & - \\
\hline Coquimbite $\mathrm{Fe}^{-3}{ }_{2}\left(\mathrm{SO}_{4}\right)_{3} \cdot 9 \mathrm{H}_{2} \mathrm{O}$ & 3.50 & - \\
\hline Bassanite $\mathrm{CaSO}_{4} \cdot 0.5 \mathrm{H}_{2} \mathrm{O}$ & 3.20 & - \\
\hline \multicolumn{3}{|l|}{ Ash analysis (\% (w/w)) } \\
\hline $\mathrm{SiO}_{2}$ & 60.69 & 44.36 \\
\hline $\mathrm{Al}_{2} \mathrm{O}_{3}$ & 22.01 & 2.79 \\
\hline $\mathrm{Fe}_{2} \mathrm{O}_{3}$ & 7.43 & 2.47 \\
\hline $\mathrm{TiO}_{2}$ & 0.92 & 0.12 \\
\hline $\mathrm{CaO}$ & 2.27 & 7.78 \\
\hline $\mathrm{MgO}$ & 2.90 & 3.96 \\
\hline $\mathrm{Na}_{2} \mathrm{O}$ & 1.06 & 0.36 \\
\hline $\mathrm{K}_{2} \mathrm{O}$ & 2.32 & 24.72 \\
\hline $\mathrm{Mn}_{3} \mathrm{O}_{4}$ & 0.06 & 0.10 \\
\hline $\mathrm{P}_{2} \mathrm{O}_{5}$ & 0.21 & 12.04 \\
\hline $\mathrm{SO}_{3}$ & - & - \\
\hline $\mathrm{BaO}$ & 0.11 & 0.05 \\
\hline
\end{tabular}

The size distribution of the fuels used is presented in Table 2.

Table 2. Size distribution of fuels (wt\% in size class)

\begin{tabular}{lll}
\hline Size $(\boldsymbol{\mu m})$ & El Cerrejon coal $(\mathbf{E C})$ & Cereal co-product $(\mathbf{C C P})$ \\
\hline 10 & - & 0.06 \\
30 & 0.40 & 6.38 \\
50 & 1.23 & 9.48 \\
70 & 5.04 & 9.94 \\
90 & 6.12 & 14.63 \\
110 & 6.52 & - \\
130 & 7.15 & 29.40 \\
150 & 4.73 & 30.11 \\
170 & 15.99 & - \\
190 & 0.24 & - \\
210 & 12.97 & - \\
230 & 39.61 & - \\
\hline
\end{tabular}




\section{Results and discussion}

\subsection{Gaseous environments}

\subsubsection{Effect of co-firing on gaseous environment}

The mean values for the gaseous species for various fuel compositions (blends of EC with 0, 25, 50 and 100\% (w/w) of CCP) are presented in Fig. 4 for the major species and in Fig. 5 for minor species, under air and oxy-firing conditions. The cases using coal are shown in the sub-figures denoted a), while the co-firing cases are denoted with $b$ ).
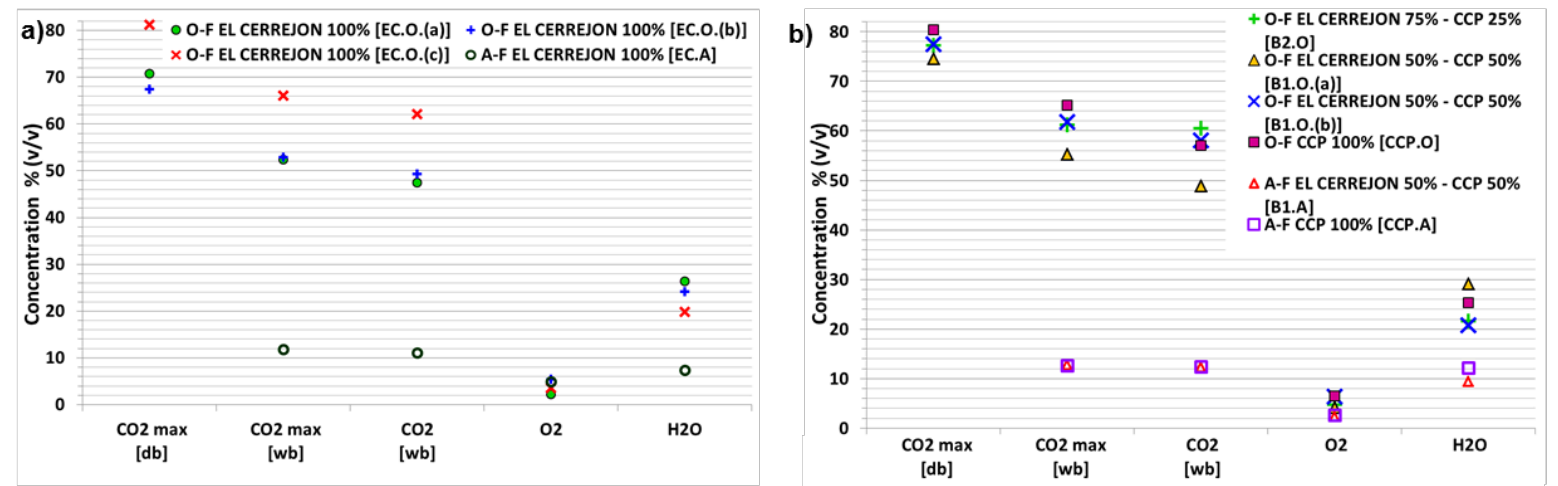

Fig. 4 Gaseous environments - major species; a) coal only, b) coal-CCP co-firing

[EC: El Cerrejon coal; CCP: Cereal co-product; B1: Blend EC50/CCP50; B2: Blend EC75/CCP25; A-F: Air-firing; O-F: Oxyfiring; db: dry basis; wb: wet basis]

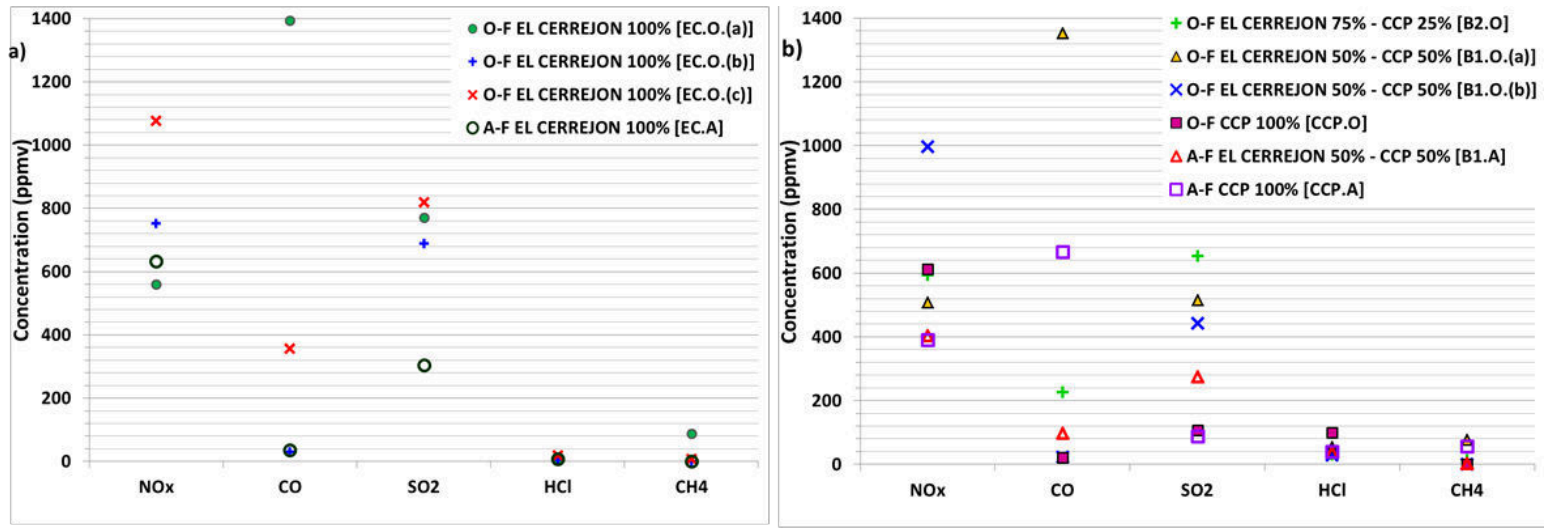

Fig. 5 Gaseous environments - minor species: a) coal only, b) coal-CCP co-firing

[EC: El Cerrejon coal; CCP: Cereal co-product; B1: Blend EC50/CCP50; B2: Blend EC75/CCP25; A-F: Air-firing; O-F: Oxyfiring; db: dry basis; wb: wet basis]

The gas composition measured for the major species shows that the maximum $\mathrm{CO}_{2}$ level reached, on a wet basis, occurs in the case of $100 \%$ coal [EC.O.(c)], as expected given the fuel analyses. Interestingly, similar values for the $\mathrm{CO}_{2}$ levels on a dry basis were achieved when using both parent fuels, in tests [EC.O.(c)] and [CCP.O]. For the $\mathrm{H}_{2} \mathrm{O}$ content, the high levels obtained are due to the fact that the condenser could not remove all the steam present in the flue gas prior to recycling. The efficiency of the condenser can be defined as the ratio (molar- or mass-basis) between the amount of the condensable species ' $i$ ' that condenses and is removed from the flue gas, after having been cooled down, and the amount of $i$ that entered the condenser. The condenser efficiencies observed for water vapour during the experiments were: $33 \%$ for $100 \%$ El Cerrejon coal, $57 \%$ for blend B1 (EC50/CCP50), 53.5\% for blend B2 (EC75/CCP25), and $86 \%$ for pure cereal co-product. The average value for water vapour in the flue gas measured inside the combustion chamber was in the range of $20-25 \%(\mathrm{v} / \mathrm{v})$, being the maximum for the case when using $100 \%$ CCP. The excess $\mathrm{O}_{2}$ was between 3.5 and $6.5 \%$ (v/v), in most cases. To help the discussion on the gas environments, Fig. 6 presents the evolution of the major and minor species for selected tests. For the minor species, the CO levels were usually under $100 \mathrm{ppm}$, but fluctuations occurred at the beginning of some of the tests, before reaching stable operation, which increased such mean values noticeably. This can be seen in Fig. 6 (d) and Fig. 6 (f) where CO peaks occurred within the first 40 minutes of operation, when the transient regime occurred. With regard to the NOx 
concentrations, the general trend shows that there are no significant changes related to the variation of the fuel; for the oxy-firing tests, NOx levels were in the range of 550-750 ppmv. The high $\mathrm{NO}_{\mathrm{x}}$ concentration, reached in the case using pure coal [EC.O.(c)], may be explained by the $\mathrm{NO}_{\mathrm{x}}$ thermal generation being promoted due to the high temperatures reached in that test. To explain the high $\mathrm{NO}_{\mathrm{x}}$ reached in the case using 50\% EC-50\% CCP blend [B1.O.(b)] in which there was an excess of oxygen around $6 \%(\mathrm{v} / \mathrm{v})$, previous work by other authors $[25,26]$ should be considered. These previous studies reported that increasing the excess of oxygen supplied to the burner led to an enhancement of NO production from the fuel-N, which seems to be the situation for this test: high levels of $\mathrm{O}_{2}$ and $50 \%(\mathrm{w} / \mathrm{w})$ of the share of CCP, which has more nitrogen in its composition than EC. The data reported for $\mathrm{SO}_{2}$ levels agree with expectations when considering the fuel analyses: higher range $(680-820 \mathrm{ppmv})$ in the tests using $100 \%$ coal, medium range (440-650 ppmv) for those tests using coal-biomass blends, and the lowest concentration (around $100 \mathrm{ppmv}$ ) for the case using only biomass. Likewise, the levels measured inside the combustor for $\mathrm{HCl}$ also follow the trend set by the ultimate analysis of the fuels: increasing with the share of biomass.
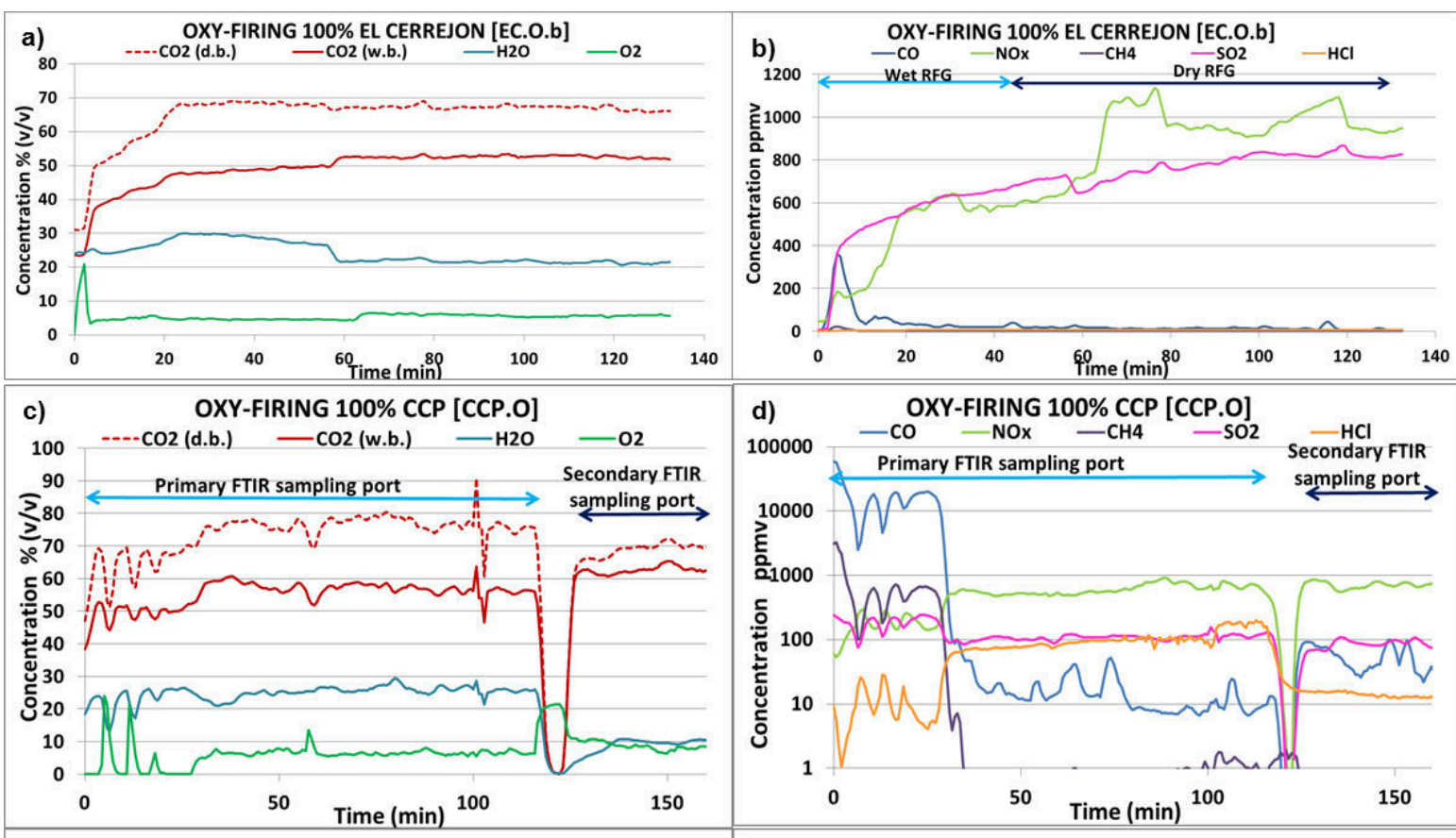

OXY-FIRING $100 \%$ CCP [CCP.O]
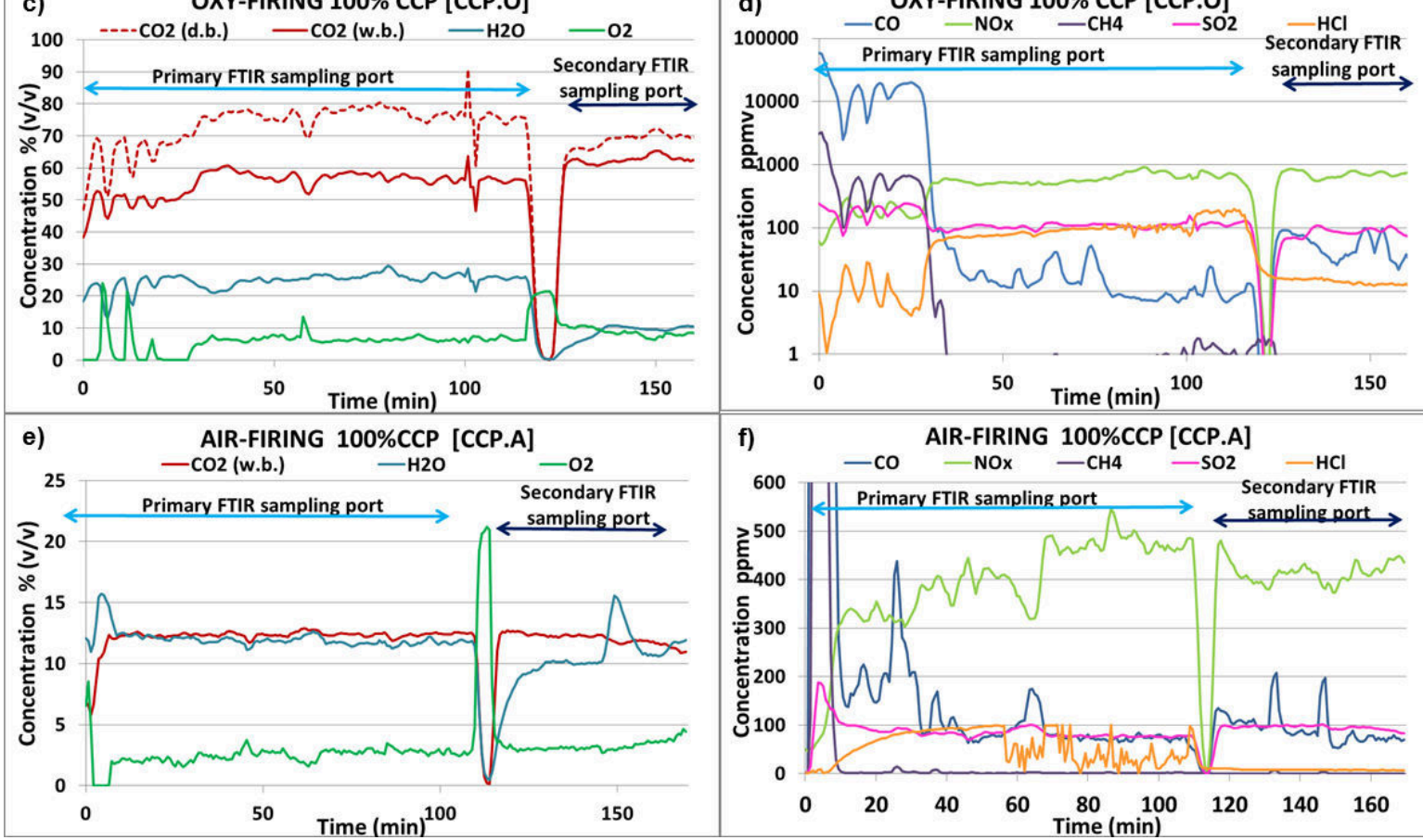

Fig. 6 Gas composition for selected tests: (a) Major species oxy-firing 100\% EC; (b) Minor species oxy-firing 100\% EC; (c) Major species oxy-firing 100\% CCP; (d) Minor species oxy-firing 100\% CCP; (e) Major species air-firing 100\% CCP; (f) Minor species

\subsubsection{Effect of oxy-firing mode on exhaust gas}

From the values reported in Fig. 5 and Fig. 6, the average gas composition obtained under air- and oxy-firing conditions can be compared. For the main species $\left(\mathrm{CO}_{2}, \mathrm{H}_{2} \mathrm{O}\right)$ - see Fig. 6 (c) and Fig. 6 (e) - and some minor species $\left(\mathrm{SO}_{2}, \mathrm{HCl}\right)$ - see Fig. 6 (d) and Fig. 6 (f) - the effect of recycling flue gas is noticeable, causing the levels to increase to two to three times their values in comparison to the air-firing case using the same fuel; this is a consequence of the accumulation inside the process of the species that are not completely removed prior to the recirculation of the flue gas to the oxy-combustor. However, the $\mathrm{NO}_{\mathrm{x}}$ levels remain similar for most cases; this means an actual decrease of $\mathrm{NO}_{\mathrm{x}}$ emissions per unit of energy produced [27]. This observation is in agreement with results reported by Toftegaard 
et al. [6] where $\mathrm{NO}_{\mathrm{x}}$ emissions were stated to be significantly reduced under oxy-firing conditions due to the near elimination of thermal $\mathrm{NO}$ formation and to re-burning of $\mathrm{NO}_{\mathrm{x}}$ passed through the burners with the recycled flue gas. Note that the higher concentrations of $\mathrm{SO}_{2}$ levels inside the oxy-combustor, previously reported in subsection 3.1.1, are not normalised per unit of energy released from the fuel; considering this normalisation the results also follow the decreasing trends when using oxy-combustion mode in comparison to air-firing. This remark is consistent with what has been reported in other studies looking at the impact of the firing mode, air vs. oxy, on the $\mathrm{SO}_{\mathrm{x}}$ emissions. This effect has been described as being small [6], or showing a decrease in the conversion from fuel-S to $\mathrm{SO}_{2}[17,28]$ under oxy-firing conditions levels, which was explained by Fleig et al.[28] to be a consequence of the higher $\mathrm{SO}_{2}$ concentrations which favour the formation of sulfates.

\subsubsection{Effect of recycle type: wet vs. dry}

As expected, all species increased in concentration except steam/water, as a consequence of changing the type of recycle (from wet to dry). This effect can be seen in Fig. 6 (a) and Fig. 6 (b), towards minute 60, when the change in the type of recycle was done during one of the oxy-firing tests. Fig. 6 (a) shows that there is an increase in $\mathrm{CO}_{2}$ levels and a decrease in $\mathrm{H}_{2} \mathrm{O}$ of around 5-8\% (v/v), with a less noticeable rise (around 3\% higher) in oxygen concentration. For the minor species, the effect of varying the type of recycle can be seen in Fig. 6 (b), particularly visible for the $\mathrm{NO}_{\mathrm{x}}$ concentration. The equivalent effect for $\mathrm{SO}_{2}$ is less pronounced, presumably due to some $\mathrm{SO}_{2}$ being extracted with water in the condenser, leaving less in the recycled flue gas.

\subsection{Ash behaviour}

\subsubsection{Fly ash characterisation}

The fly ash was collected from two different locations: the horizontal section of the combustor (A) and the cyclone (B). The aim of analysing these samples was to evaluate the unburnt carbon present in the ash settled during the tests, to get a better understanding of whether the fuel used (coal/biomass/blends) or the firing mode (air/oxy-firing) had a noticeable effect on the carbon burnout of the fly ash generated. Fig. 7 shows the crucibles containing the ashes evaluated, before and after the unburnt carbon-in-ash tests. An empty crucible was used in all the tests, to identify any systematic changes in measurements resulting from variations in the tests' environmental conditions, giving changes in readings which were not due to the mass loss of the sample during the combustion process but were due to differences from one day to another in environmental humidity, ambient pressure, etc.

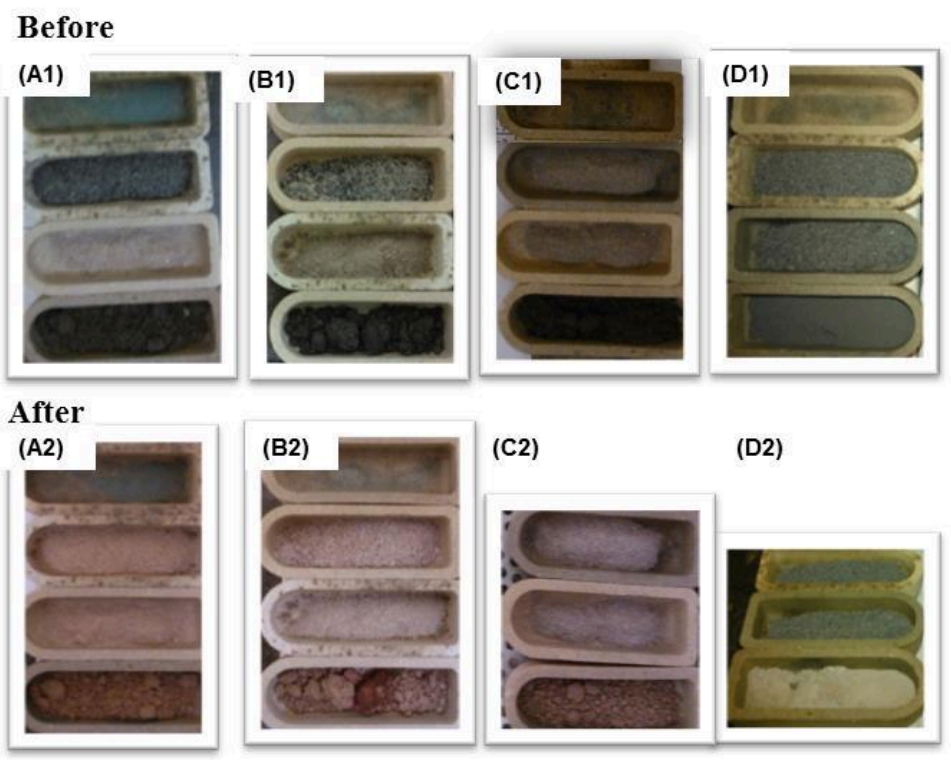

Fig. 7. Samples for unburnt carbon in ash from oxy-firing experiments before (1) and after (2) the burnout tests: (A) 100\% EC; (B) 75\% EC-25\% CCP; (C) $50 \%$ EC-50\% CCP; (D) $100 \%$ CCP

The results obtained after performing the unburnt carbon-in-ash analyses using the technique already explained in the experimental procedure (see subsection 2.2.2) are presented in Table 3. 
[EC: El Cerrejon coal; CCP: Cereal co-product; B1: Blend EC50/CCP50; B2: Blend EC75/CCP25; A-F: Air-firing; O-F: Oxyfiring]

\begin{tabular}{llllllllll}
\hline $\begin{array}{l}\text { Sampling } \\
\text { point }\end{array}$ & EC.A & B1.A & CCP.A & EC.O. (b) & EC.O. (c) & B1.O. (a) & B1.O. (b) & B2.O & CCP.O \\
\hline A & 31.4 & - & - & - & 43.5 & - & - & 30.5 & - \\
B & 38.3 & 33.2 & 30.0 & 9.4 & 7.4 & 11.4 & 16.2 & 8.9 & 8.3 \\
\hline
\end{tabular}

The unburnt carbon in the ash from the horizontal section of the combustor (denoted with A) is quite high in all cases, possibly due to incompletely burned fuel particles separating from the main gas flow. High levels are also found for the cyclone ash samples in all air firing cases. . However, there was significantly less unburnt carbon cyclone ash in the oxy-firing cases compared to air-firing, suggesting that combustion is continuing along the gas path between $\mathrm{A}$ and $\mathrm{B}$ under oxy-firing conditions, as a consequence of the higher temperatures and $\mathrm{O}_{2}$ concentration for the oxy-firing tests. A further possible reason for the overall high levels in unburnt carbon observed in the fly ashes could relate to the particle size distributions of the fuels, with an excessive fraction of large particles, in which EC was supplied, as can be seen in Table 2.

\subsubsection{Deposit characterisation}

The ash deposits formed after approximately $3 \mathrm{~h}$ of steady operation are presented in Fig. 8. It can be seen that the amounts of deposit generated for the cases when using pure biomass are noticeably higher than for the cases using pure coal or coal/biomass blends. Another observation is that changing the firing mode does not seem to have as great an effect on deposit build-up as varying the fuel blend. This fact has been previously observed by other authors [19] and identified as a consequence of the higher alkali content of biomass fuels, such as CCP, resulting in stickier particles, leading to softer, lower-density deposits, thus raising the rate of deposit build-up. The high content of alkalis detected in deposits from $100 \%$ CCP cases, particularly potassium, will be discussed in the subsection dedicated to ESEM analyses (see 3.2.2.1).
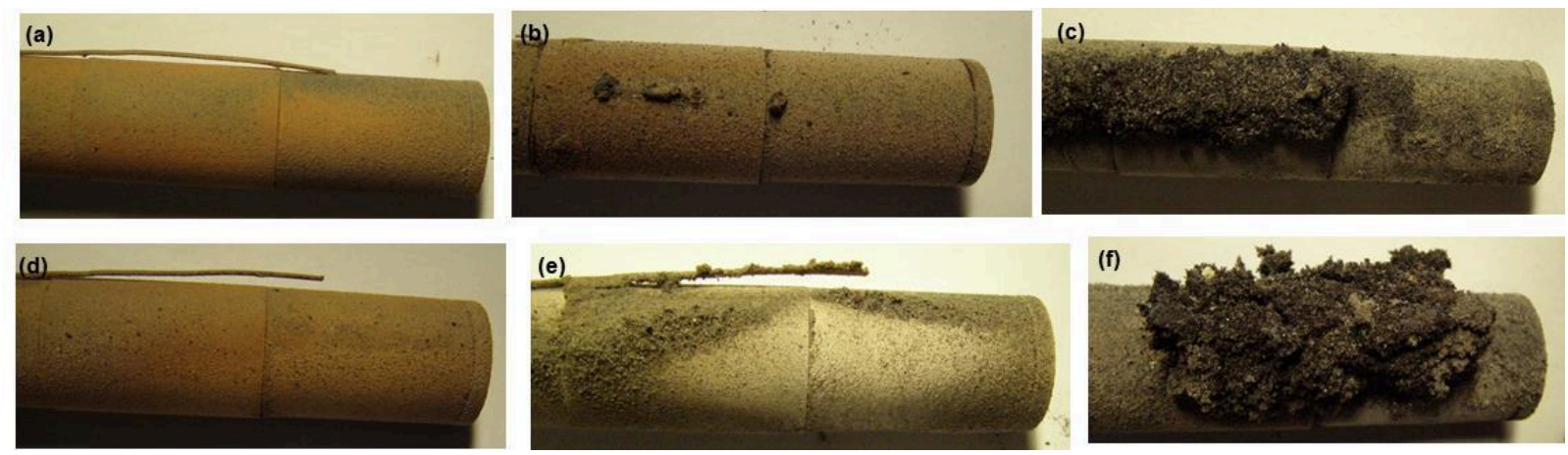

Fig. 8. Images of ash deposits formed on the probes: (a) Air- firing 100\% EC; (b) Air-firing 50\% EC-50\% CCP; (c) Air-firing 100\% CCP; (d) Oxy- firing 100\% EC; (e) Oxy-firing $50 \%$ EC-50\% CCP; (f) Oxy-firing 100\% CCP

It was also noted that the unburnt carbon contents of the deposit samples taken from the deposition probes showed $100 \%$ burn-out for all the cases: air and oxy-firing.

\subsubsection{ESEM/EDX analyses}

Fig. 9 presents the micrographs (at the same magnification) generated for different deposit samples during the ESEM/EDX analyses. These images show the differences in particle sizes found between the ash deposits when varying the fuel blend and when changing the type of firing mode from air to oxy-firing. The most perceptible effect is the increasing deposit particle size with increasing levels of CCP, for both air-firing and oxy-firing. The more fibrous appearance for the cases with higher shares of biomass can also be observed, reflecting the biomass cellulose structure. These fibres are mostly rich in $\mathrm{Si}$, but sometimes appear together with $\mathrm{K}$ or $\mathrm{Ca}$. The rounded/spherical particles with surface pores shown in the images are the result of ash melting and expansion of gas evolution from the residual carbon-rich material. These are greater for the higher share of CCP as a consequence of the lower ash fusion temperatures comprising high contents of $\mathrm{Si}$ and $\mathrm{K}$, along with $\mathrm{P}$ or $\mathrm{S}$ levels in some particles. In all cases it should be expected that these particles contain largely amorphous material from the partial decomposition of the minerals in the 

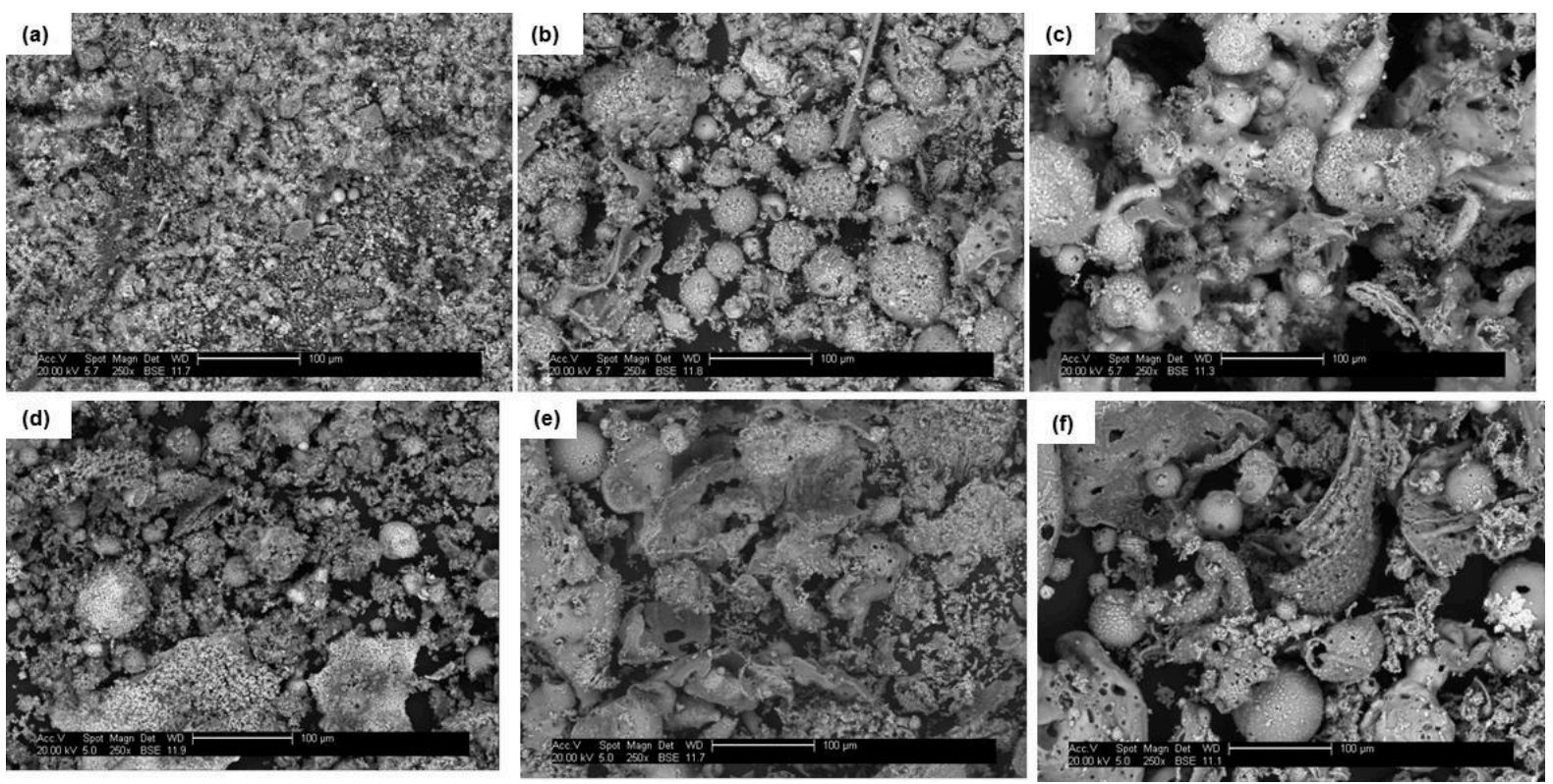

Fig. 9. ESEM images: (a) Air- firing 100\% EC; (b) Air-firing 50\% EC-50\% CCP; (c) Air-firing 100\% CCP; (d) Oxy- firing $100 \%$ EC; (e) Oxy-firing $50 \%$ EC-50\% CCP; (f) Oxy-firing $100 \%$ CCP

Results from the ESEM/EDX analyses of the deposits are shown in Fig. 10. The reference considered to evaluate these results is the mineral and the ash analyses of the parent fuels presented in Table 1. The ESEM/EDX results for the deposits sampled at high temperature $\left(\sim 750^{\circ} \mathrm{C}\right)$ are presented in Fig. 10(a). The majority of the elements detected follow the trends shown in the fuel ash analyses, with a tendency for $\mathrm{Na}, \mathrm{Al}$, Ti and $\mathrm{Fe}$ to increase with the share of $\mathrm{EC}$ in the fuel blend. On the other hand, the contents of $\mathrm{Mg}, \mathrm{P}, \mathrm{K}, \mathrm{Ca}$ and $\mathrm{Cl}$ increase with the share of biomass used. For the particular case of $\mathrm{P}$, this trend is less marked than might have been expected from the ash analyses of the parent fuels, but this is consistent with experience of phosphates condensing to form adherent deposits on lowertemperature surfaces (e.g., economisers) further along the flue gas path. It is interesting to note the low $\mathrm{K}$ contents obtained for the tests using $100 \% \mathrm{EC}$, consistent with the fact that, generally, in coals, this element is mostly present in clay minerals (e.g. illite), restricting its release as vapour-phase $\mathrm{K}$ species (higher temperatures are required to release $\mathrm{K}$ from illite). This is contrary to what happens in the case of biomass where the $\mathrm{K}$ is not bound in clay minerals, but is rather in an organic form from which it is easily released. The two elements that do not show clear patterns are $\mathrm{Si}$ and $\mathrm{S}$. The Si contents are similar for all the cases reported, even though it should be higher for those cases with greater share of EC on a law of mixtures basis. The tests with maximum Si levels are those using the coalbiomass blend $50 \% \mathrm{EC}-50 \% \mathrm{CCP}$, and $100 \% \mathrm{CCP}$. An interesting ratio to examine is that between aluminium and silicon. The $\mathrm{Al} / \mathrm{Si}$ ratios detected for cases using coal-biomass blends and pure biomass correspond to the ratios in the parent fuels presented in Table 1. However, the Al/Si ratio resulting for the cases using $100 \% \mathrm{EC}$, under air and oxyfiring, is twice the value of the ratio expected. For the $\mathrm{S}$ content, similar values are observed when using pure biomass or coal, even though the ultimate analysis, presented in Table 1, shows that EC has 3.5 times more sulphur than CCP. This fact may be due to the retention of sulphur in the ash deposits by the potassium, present to a greater extent in the biomass, leading to higher levels of $\mathrm{K}_{2} \mathrm{SO}_{4}$ in the high-CCP blend deposits. This assumption will be justified in the following subsection (3.2.2.2), where the results from the XRD analyses are presented, giving details about the compounds present in the ash deposits.

Fig. 10(b) presents the results of the ESEM/EDX analyses of the ashes sampled at medium temperature $\left(\sim 650^{\circ} \mathrm{C}\right)$. The observations made for the deposits at high temperature $\left(\sim 750^{\circ} \mathrm{C}\right)$ are repeated, in general, for the results at medium temperature, although some additional remarks must be made for $\mathrm{Al} / \mathrm{Si}$ ratios and $\mathrm{S}$. For the $\mathrm{Al} / \mathrm{Si}$ ratios, similar to the results reported for high temperature, only the cases using coal-biomass blends and pure biomass kept the $\mathrm{Al} / \mathrm{Si}$ ratios shown in the parent fuels ash analyses in Table 1 . The $\mathrm{S}$ levels show a maximum for the tests using coal-biomass blends, and a minimum when using 100\% CCP. However, the levels reached for the tests with $100 \%$ $\mathrm{CCP}$ are still higher than expected considering the ultimate analyses of the parent fuels; the most probable explanation 

firing.

(a)

ASH DEPOSITS - High T (750C) Probes

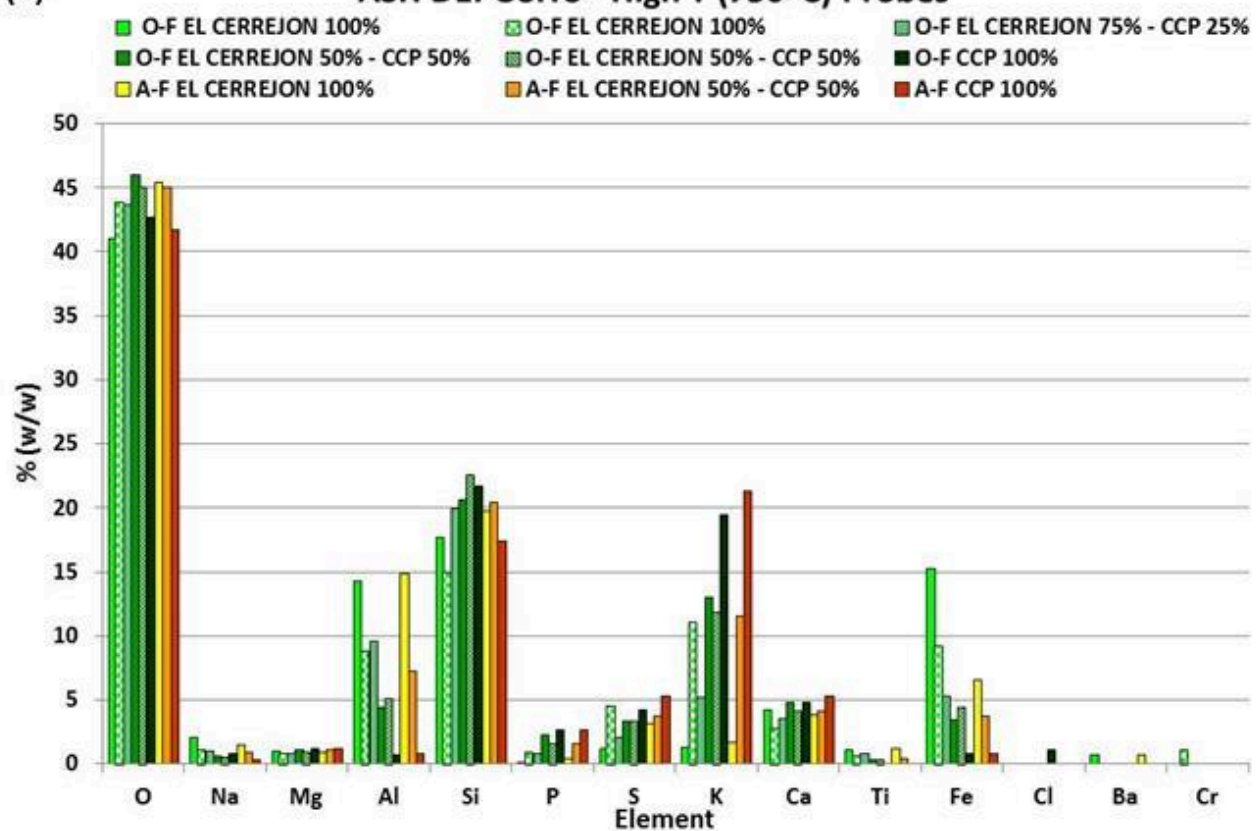

(b) ASH DEPOSITS - Medium T (650ㄷ) Probes

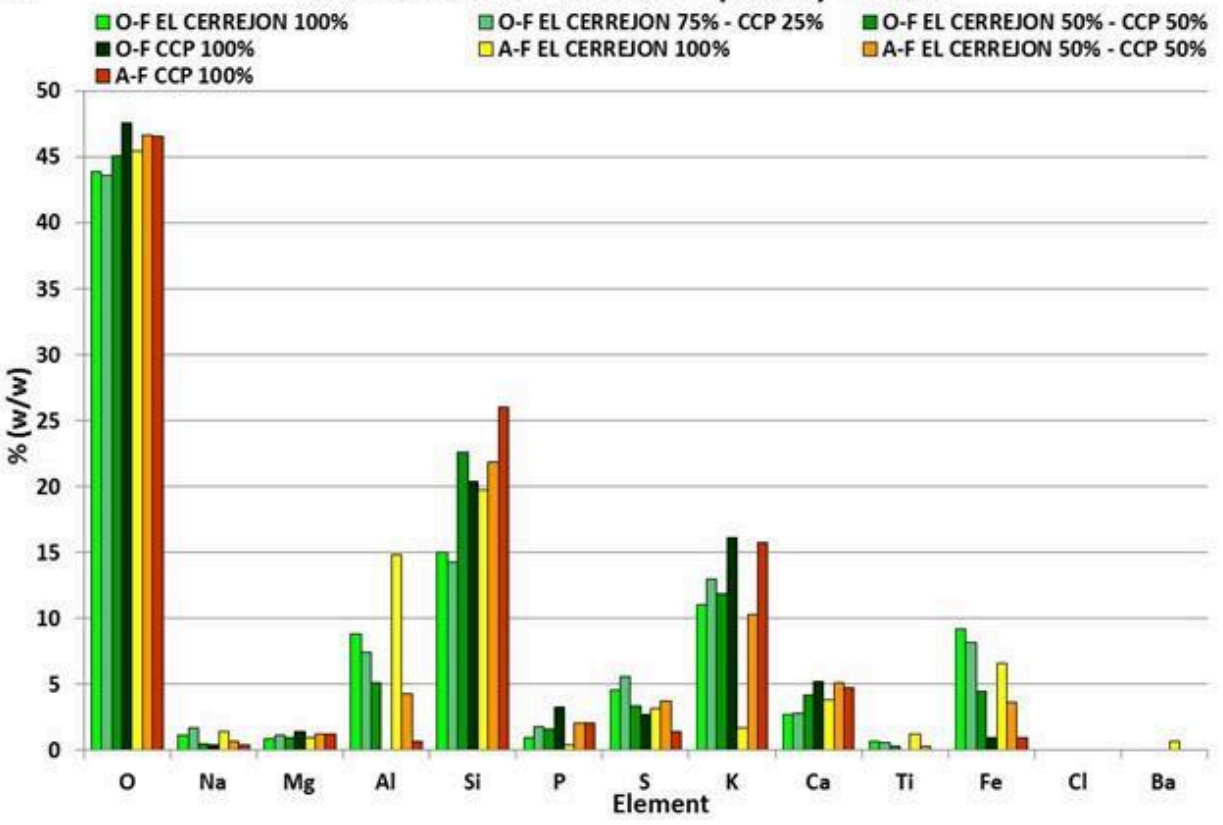

Fig. 10. Elemental analyses of deposits sampled at: (a) $750^{\circ} \mathrm{C}$; (b) $650^{\circ} \mathrm{C}$, varying fuel and firing mode.

More details on the data obtained during this experimental work, such as temperature profiles inside the combustion chamber or heat fluxes, can be found in a previous publication [8].

\subsubsection{XRD analyses}

For the evaluation of the XRD results, comparisons have been made to get a better understanding of how a change in fuel blend and/or the firing mode affect the composition of the ash deposits. Air and oxy-firing were, therefore, compared for a given type of fuel. Comparison was also made between results generated when the fuel was varied from $100 \%$ coal to $100 \%$ biomass for a given combustion mode.

For the case using 100\% EC, the patterns generated for deposits sampled under air-firing (black) and under oxyfiring conditions (red) are illustrated in Fig. 11. The peaks corresponding to crystalline compounds observed as 
different between the two cases are highlighted and labelled in the graph. However, the high background level shown is consistent with most of the material being amorphous in the samples analysed, as observed in the ESEM micrographs presented earlier, and so the crystalline phases identified represent only minor species in the deposits and may not be of real significance. This phenomenon is more important for the cases evaluating biomass ash, as they have been reported to have a greater non-crystalline character compared to coal ash [29]. Under oxy-firing conditions using $100 \%$ coal, crystalline compounds such as quartz, coquimbite, illite and pyrite are found at higher levels than in the air-firing case. Quartz is often found in ash and deposit samples and is of little significance as very small amounts can show in XRD analysis. The presence of the clay mineral illite and pyrites, along with the partially oxidised Fe/S compound coquimbite, are surprising and suggest that some ash particles reached the deposit probes either during or after the tests without having been through a high-temperature flame; illite particles would normally be expected to have been transformed into an amorphous alumina-silicate phase, and pyrites into an Fe oxide if they had reached flame temperatures heated during combustion. Also, the presence of fluid matter as a mineralised aqueous solution (e.g., coquimbite) is expected in those cases analysing biomass ash but it is more unusual when looking at coal ash, according to Vassilev et al. [29]. The only compound found at higher concentration in air combustion was sillimanite (an alumino-silicate) which is derived during the decomposition of clay minerals (such as kaolinite which transforms and recrystallizes more readily than illite).

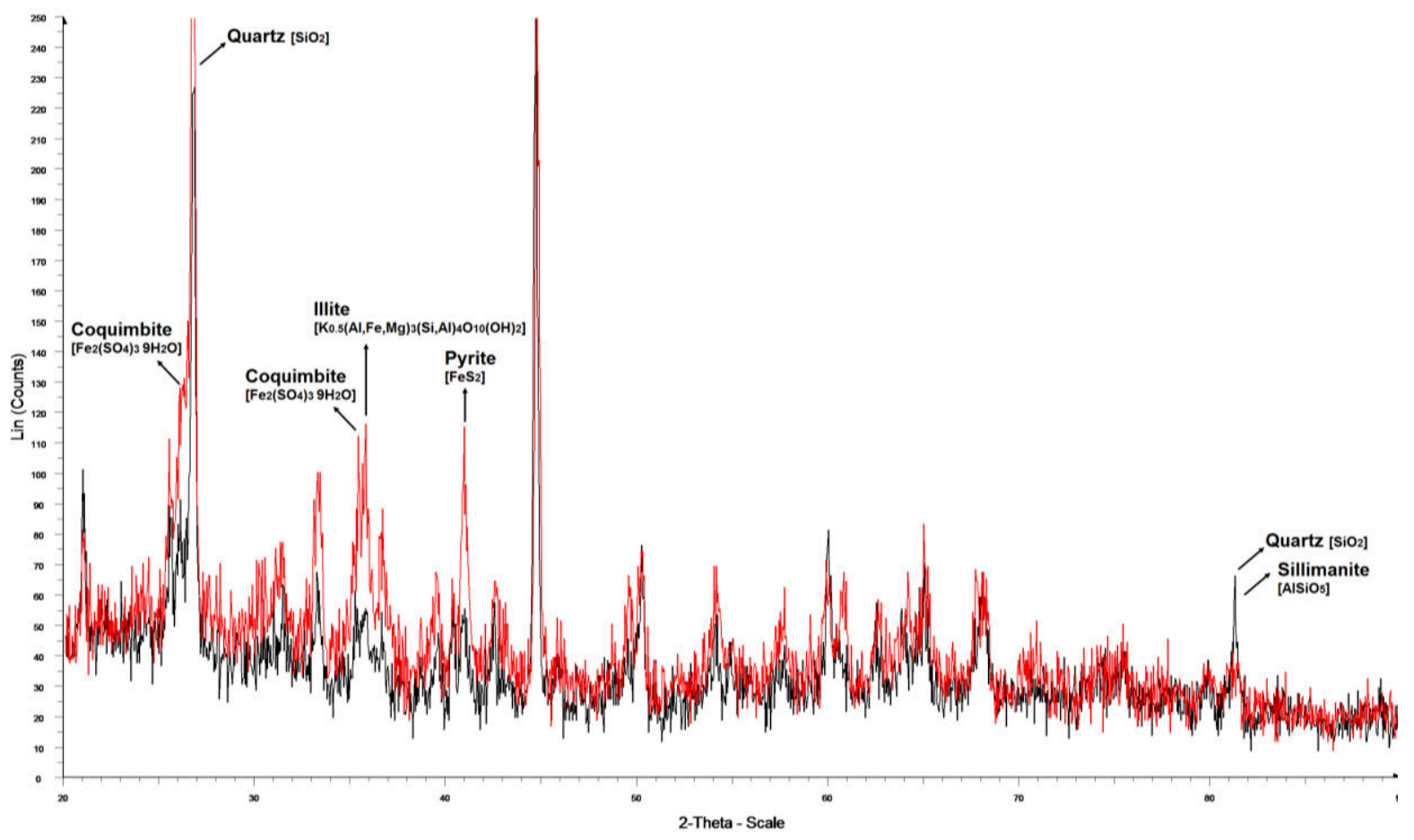

Fig. 11. XRD charts for EC ashes collected at $640-700^{\circ} \mathrm{C}$ : air-firing (black spectrum) vs. oxy-firing (red spectrum)

For the case using 50\% EC-50\% CCP, the spectra generated for ashes sampled under air-firing (red) and under oxy-firing conditions (black) are illustrated in Fig. 12 (the colours in this figure and in Fig 13 are reversed from those in Fig 11). There are fewer crystalline compounds to be seen in this case, indicating that a higher proportion of the deposit material is amorphous, in accordance with the view that biomass ash has a marked non-crystalline character [29]. Those peaks found relate to minor amounts of sapphirine (a silicate of magnesium and aluminium) and aphthitalite (a potassium sulphate mineral) under oxy-firing conditions. The sulphates and silicates found in this instance are in agreement with the classification given by Vassilev et al. [4] where coal ash is expected to present higher levels of these species. 


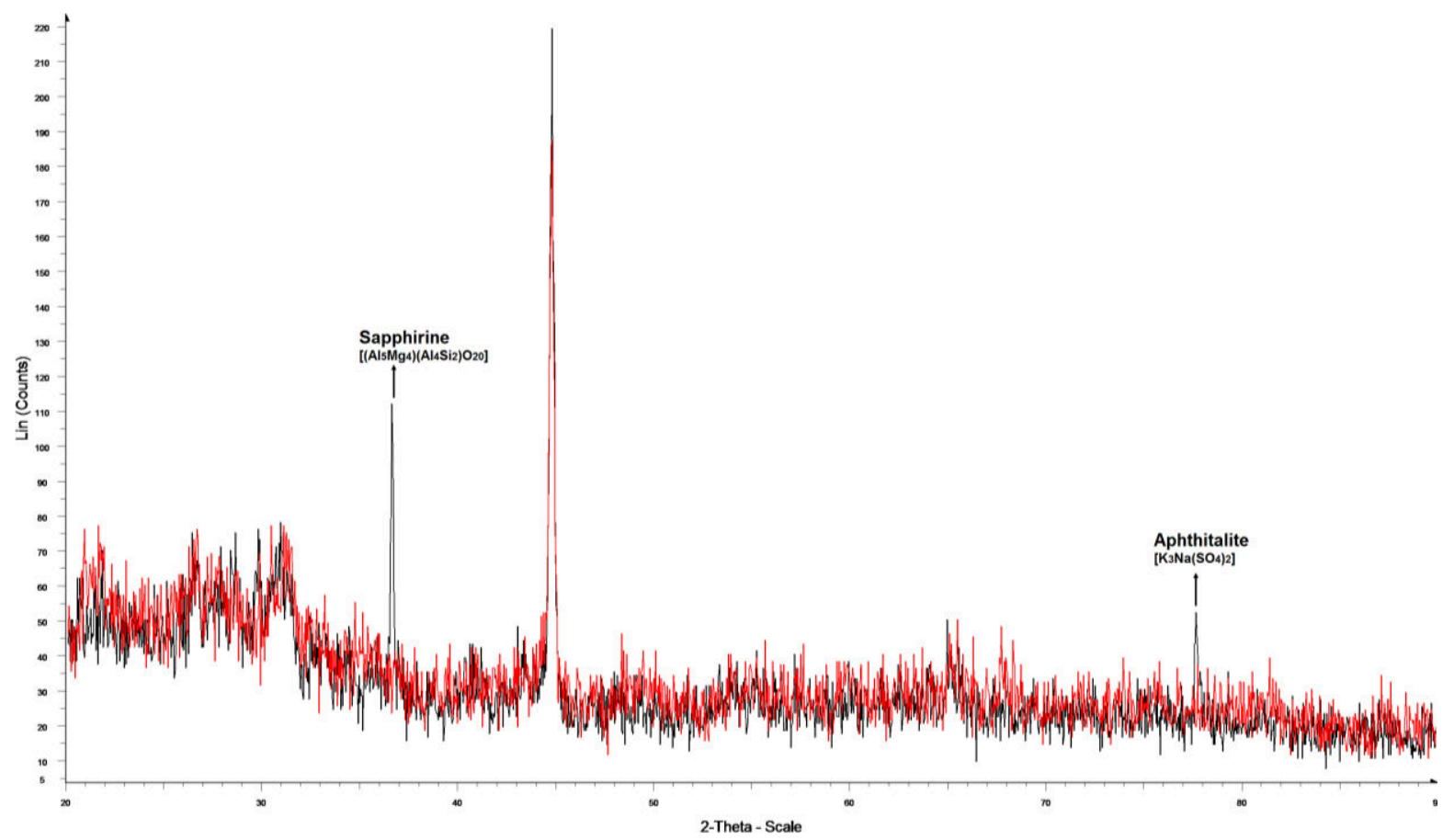

Fig. 12. XRD charts for $50 \%$ EC -50\% CCP ashes collected at 610-650 ${ }^{\circ} \mathrm{C}$ : air-firing (red spectrum) vs. oxy-firing (black spectrum)

For the case using $100 \%$ CCP, the spectra generated for deposits sampled under air-firing (red) and under oxyfiring conditions (black) are illustrated in Fig. 13. Contrary to the situation when pure EC or EC-CCP blend were used, using pure CCP leads to higher levels of a range of different compounds for the air-firing case. Some of the $\mathrm{Si}$ present is in the form of cristobalite $\left(\mathrm{SiO}_{2}\right)$, but also some aluminium-iron-silicon compounds. Other compounds such as aluminium phosphate and arcanite $\left(\mathrm{K}_{2} \mathrm{SO}_{4}\right)$ appear to reach higher concentrations under air-firing conditions. The mineral matter present in these biomass ashes shows chlorides and phosphates, as expected based on the literature [4].

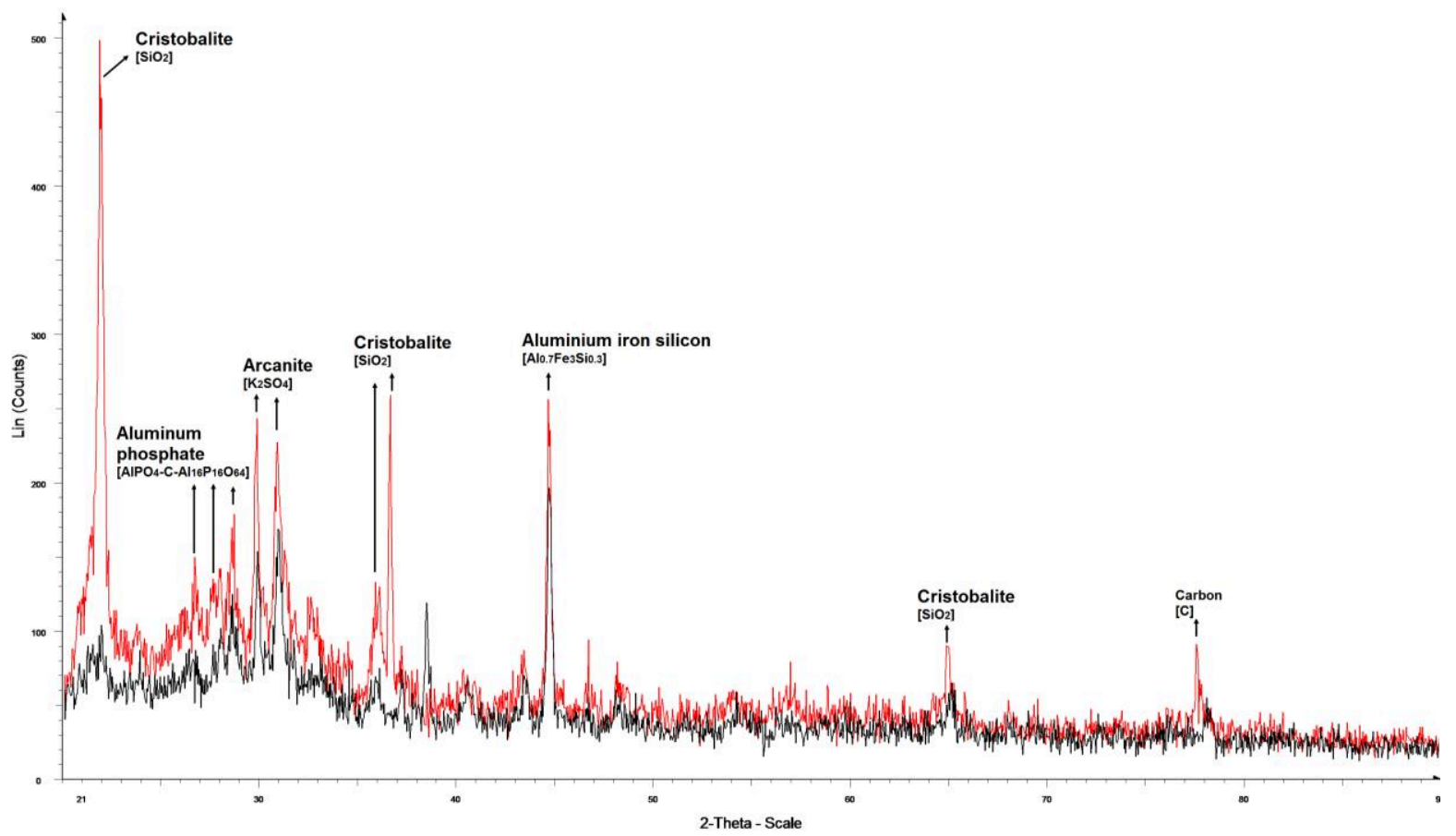

Fig. 13. XRD charts for $100 \% \mathrm{CCP}$ ashes collected at $650-680^{\circ} \mathrm{C}$ : air-firing (red spectrum) vs. oxy-firing (black spectrum)

For the comparison of the results obtained for $100 \% \mathrm{EC}$ and $100 \% \mathrm{CCP}$ under oxy-firing conditions, the corresponding spectra are presented in Fig. 14. From this figure, it can be seen that crystalline compounds such as quartz $\left(\mathrm{SiO}_{2}\right)$, aluminium-iron-silicon, coquimbite and pyrite are dominant for ashes generated when oxy-firing $100 \%$ 
EC, which is compatible with the expected components for coal ash according to the relevant literature [4]; this also indicates incomplete transformation of the coal minerals as suggested above. On the other hand, when using $100 \%$ $\mathrm{CCP}$, cristobalite (a high-temperature form of $\left.\mathrm{SiO}_{2}\right)$, potassium sulphur oxide $\left(\mathrm{K}_{2} \mathrm{SO}_{4}\right)$ and potassium magnesium chloride $\left(\mathrm{KMgCl}_{2}\right)$ were found, fully consistent with the composition of CCP ash.

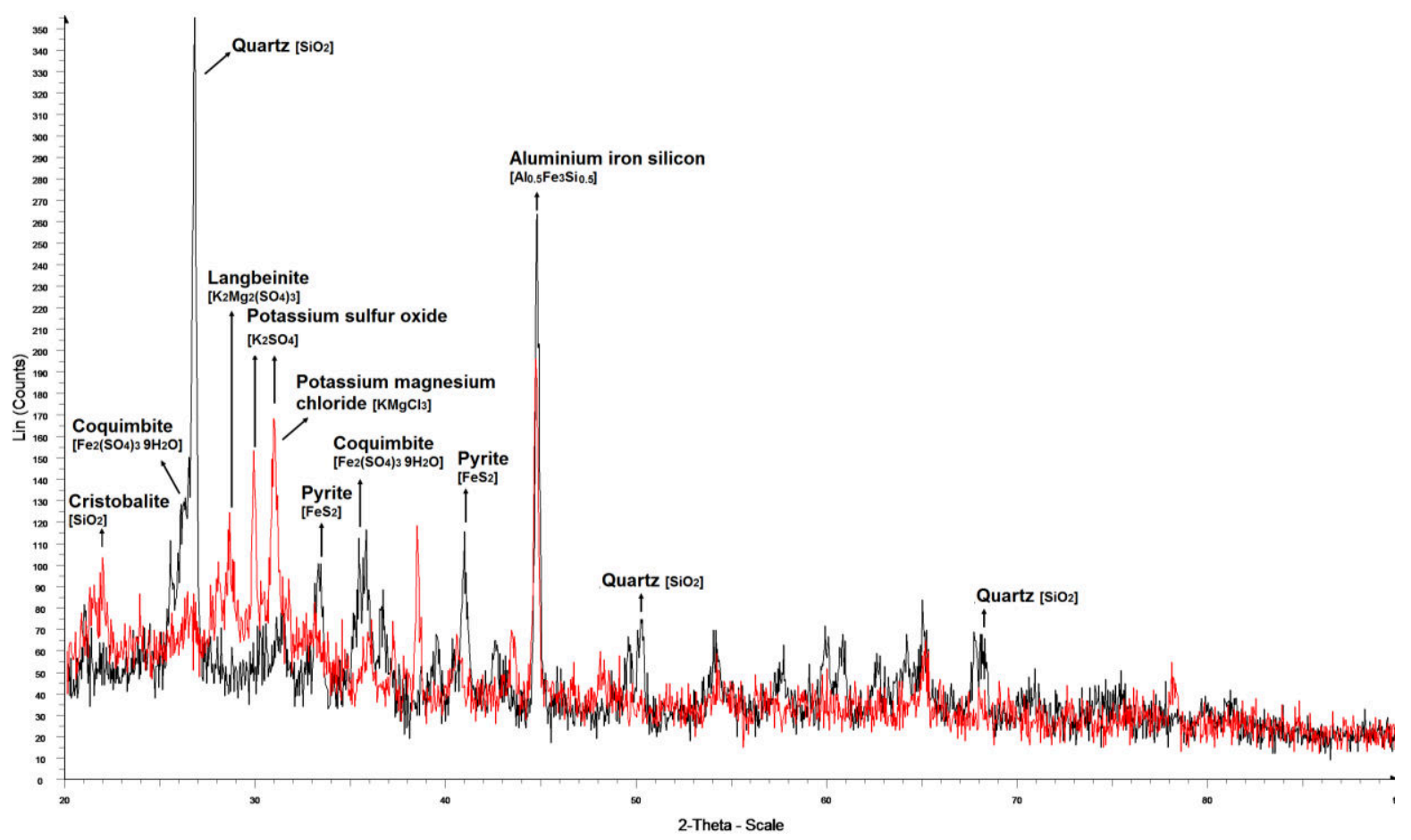

Fig. 14. XRD charts for oxy-firing ashes collected at $680-700^{\circ} \mathrm{C}: 100 \% \mathrm{EC}$ (black spectrum) vs. $100 \% \mathrm{CCP}$ (red spectrum)

\section{Discussion of findings and technological implications}

The series of pilot-scale tests carried out co-firing a biomass feedstock (CCP) with addition of 0, 50, 75 and 100\% (w/w) of EC under air and oxy-firing conditions have provided new information on the gaseous environments the compositions and characteristics of the fly ash and ash deposits formed on air-cooled deposit probes with surface temperatures in the range from 650 to $750^{\circ} \mathrm{C}$ (to simulate operating temperatures similar to those reached by superheaters/reheaters at industrial-scale facilities).

It was found that similar $\mathrm{CO}_{2}$ levels can be reached, on a dry basis, using $100 \%$ coal or $100 \%$ biomass. The $\mathrm{H}_{2} \mathrm{O}$ levels measured in oxy-combustion tests with no flue gas treatment prior to gas recycle showed concentrations up to three times higher than in combustion with air. As expected, the flue gas generated using a high share of biomass (without any flue gas treatment prior to recycle) will have higher $\mathrm{H}_{2} \mathrm{O}$ content, as a consequence of the higher $\mathrm{H}_{2}$ and $\mathrm{O}_{2}$ concentrations of the biomass. The presence of this additional $\mathrm{H}_{2} \mathrm{O}$ needs to be considered when designing the flue gas recycle system to avoid acid dew point corrosion problems in the recycle gas path when using blends with high biomass content.

The main difference between air and oxy-combustion was the increase in the $\mathrm{SO}_{2}$ content, which was up to 2.6 times higher when using coal in oxy-combustion compared to the same case under air-firing conditions (without considering normalisation per unit of energy released from the fuel); this is a direct consequence of the recycle of those species which are not removed before re-injection of the flue gas into the combustor. With an increasing share of biomass in the fuel blend, the $\mathrm{SO}_{2}$ levels decreased while $\mathrm{HCl}$ levels increased, as expected from the ultimate analysis of the parent fuels. No significant variations in the $\mathrm{NO}_{\mathrm{x}}$ levels were found with changed levels of biomass, except for the 50/50 blend, where high levels of excess oxygen were supplied ( $6 \%(\mathrm{v} / \mathrm{v}))$, causing an increase in the NOx generation from the fuel-N (biomass presents higher $\mathrm{N}$ contents than coal in its ultimate analysis). Additionally, it has been described when analysing the effect of the firing mode , air vs. oxy, on the emissions generated, that the presence of $\mathrm{SO}_{2}$ and $\mathrm{NO}_{\mathrm{x}}$ in the flue gas must be evaluated on the basis of normalised results; by doing this, the results showed a decrease in the levels of $\mathrm{SO}_{2}$ and $\mathrm{NO}_{\mathrm{x}}$ under oxy-firing conditions, a fact that is consistent with findings from other researchers $[6,17,28]$. The effect of the type of recycle (wet vs. dry), revealed increases in the 
concentrations reached for all species except steam, as expected. The minor species $\mathrm{NO}_{\mathrm{x}}$ and $\mathrm{SO}_{2}$ were found to be especially sensitive to this change.

While the results for the carbon in ash were not fully consistent, elevated levels were observed in the air-firing cases compared to oxy-firing, where the combustion process is assumed to be enhanced by the higher $\mathrm{O}_{2}$ concentrations and higher temperatures reached. However, no clear trend was found by varying the type of fuel.

The other major aspect of the study was to investigate ash deposition with respect to the relative risks of fouling and corrosion in oxy-firing and when a high share of biomass was used in the fuel blend. The extent of deposition increased with an increasing share of biomass, but did not show any perceptible change between air- and oxy-firing; and so similar measures (e.g., soot blowers) to restrict the build-up of ash deposits should be applicable. Larger particles were found in the deposits generated using pure biomass, without showing noticeable differences when varying the firing mode.

The deposit compositions showed similar patterns at high $\left(750^{\circ} \mathrm{C}\right)$ and medium $\left(650^{\circ} \mathrm{C}\right)$ deposition temperatures, where most of the elements followed the trend demonstrated by the fuel analyses. The main exception found to these trends was for $\mathrm{S}$, as similar S levels were found in all cases, even though EC has 3.5 times more S than CCP. This is consistent with the higher $\mathrm{K}$ levels contained in the biomass leading to much greater formation and deposition of $\mathrm{K}_{2} \mathrm{SO}_{4}$. The low $\mathrm{K}$ contents obtained for cases using EC are consistent with the fact that this element tends to be mixed with the clay present in coals, limiting its release. $\mathrm{Cl}$ was detected in the ash deposits for the cases using pure biomass under oxy-firing conditions. The higher levels of $\mathrm{S}$ and $\mathrm{Cl}$ in deposits when $100 \% \mathrm{CCP}$ was fired were confirmed by the XRD analyses which, under air-firing conditions showed the presence of arcanite $\left(\mathrm{K}_{2} \mathrm{SO}_{4}\right)$ as well as an indication of the presence of potassium magnesium chloride. The presence of sulphate and, in particular, chloride species in the deposits are a concern with respect to fireside corrosion [5], although both species are routinely found in deposits in biomass boilers. In these systems, efforts are made to minimise the presence of chloride species which lead to the very aggressive corrosion mechanisms found in waste incineration and to reduce the plant's steam parameters, and hence superheater/reheater metal temperatures to obtain economically viable component lives. Fireside corrosion risks [5] in these systems increase with higher fluxes of sulphate species in the deposits formed, and so similar measures can be used to address these risks in both air- and oxy-firing systems using high shares of biomass.

\section{Conclusions}

The experimental study of the co-firing of coal and biomass under air- and oxy-firing conditions has generated new information on the gaseous environments prevailing in the combustion gas path and on the deposition behaviour of the ash. While the study has been limited to one type of coal and one type of biomass, it has provided clear information in support of the view that experience from air-firing can be readily translated to oxy-firing systems with reasonable confidence. Ash deposition behaviour was found to be similar in both air- and oxy-firing, indicating that similar approaches to handle ash fouling and fireside corrosion can be used in both cases. Studies with other coals and biomass fuels are required to ensure that this conclusion can be applied widely.

\section{Acknowledgements}

The authors gratefully acknowledge the E.ON and UK Engineering and Physical Sciences Research Council (EPSRC) funding and lead via the Oxyfuel Combustion - Academic Programme for the UK (OxyCAP) Consortium. The authors would also like to thank Dr. Mohamad J Al-Jeboori and Dr Paul Fennell from Imperial College London for their help with the analyses of size distribution of the fuels used for this work.

\section{References}

[1] International Energy Agency. CO2 Emissions From Fuel Combustion Highlights. IEA Statistics 2013:158. doi:10.1787/co2-table2011-1-en.

[2] UK Parliament. Climate Change Act 2008 2008:1-103. doi:10.1136/bmj.39469.569815.47.

[3] Adams D. Flue gas treatment for CO 2 capture. Report CCC/169 IEA Clean Coal Centre. ISBN 978-92-9029-489-4. 2010. 
[4] Vassilev S V., Vassileva CG, Vassilev VS. Advantages and disadvantages of composition and properties of biomass in comparison with coal: An overview. Fuel 2015;158:330-50. doi:10.1016/j.fuel.2015.05.050.

[5] Arias B, Pevida C, Rubiera F, Pis JJ. Effect of biomass blending on coal ignition and burnout during oxy-fuel combustion. Fue 2008;87:2753-9. doi:10.1016/j.fuel.2008.01.020.

[6] Toftegaard MB, Brix J, Jensen P a., Glarborg P, Jensen AD. Oxy-fuel combustion of solid fuels. Progress in Energy and Combustion Science 2010;36:581-625. doi:10.1016/j.pecs.2010.02.001.

[7] Smart JP, Patel R, Riley GS. Oxy-fuel combustion of coal and biomass, the effect on radiative and convective heat transfer and burnout. Combustion and Flame 2010;157:2230-40. doi:10.1016/j.combustflame.2010.07.013.

[8] Jurado N, Darabkhani HG, Anthony EJ, Oakey JE. Oxy-combustion Studies Into the Co -Firing of Coal and Biomass Blends: Effects on Heat Transfer, Gas and Ash Compositions. Energy Procedia 2014;63:440-52. doi:10.1016/j.egypro.2014.11.047.

[9] Syed AU, Simms NJ, Oakey JE. Fireside corrosion of superheaters: Effects of air and oxy-firing of coal and biomass. Fuel 2012;101:62-73. doi:10.1016/j.fuel.2011.03.010.

[10] Khodier A, Simms N. Investigation of gaseous emissions and ash deposition in a pilot-scale PF combustor co-firing cereal coproduct biomass with coal. Conference on Renewable Energies and Power Quality 2010.

[11] Bartolomé C, Gil A, Ramos I. Ash deposition behavior of cynara-coal blends in a PF pilot furnace. Fuel Processing Technology 2010;91:1576-84. doi:10.1016/j.fuproc.2010.06.005.

[12] Chen L, Yong SZ, Ghoniem AF. Oxy-fuel combustion of pulverized coal: Characterization, fundamentals, stabilization and CFD modeling. Progress in Energy and Combustion Science 2012;38:156-214. doi:10.1016/j.pecs.2011.09.003.

[13] Galloway BD, Sasmaz E, Padak B. Binding of SO3 to fly ash components: CaO, MgO, Na2O and K2O. Fuel 2015;145:79-83. doi:10.1016/j.fuel.2014.12.046.

[14] Jiménez S, Ballester J. Effect of co-firing on the properties of submicron aerosols from biomass combustion. Proceedings of the Combustion Institute 2005;30:2965-72. doi:10.1016/j.proci.2004.08.099.

[15] Valmari T. Potassium behaviour during combustion of wood in circulating fluidised bed power plants. VTT Publications 2000.

[16] Kassman H, Bäfver L, Åmand LE. The importance of SO2 and SO3 for sulphation of gaseous KCl - An experimental investigation in a biomass fired CFB boiler. Combustion and Flame 2010;157:1649-57. doi:10.1016/j.combustflame.2010.05.012.

[17] Spörl R, Maier J, Scheffknecht G. Sulphur Oxide Emissions from Dust-fired Oxy-fuel Combustion of Coal. Energy Procedia 2013;37:1435-47. doi:10.1016/j.egypro.2013.06.019.

[18] Li W, Wang L, Qiao Y, Lin J-Y, Wang M, Chang L. Effect of atmosphere on the release behavior of alkali and alkaline earth metals during coal oxy-fuel combustion. Fuel 2015;139:164-70. doi:10.1016/j.fuel.2014.08.056.

[19] Hussain T, Khodier AHM, Simms NJ. Co-combustion of cereal co-product (CCP) with a UK coal (Daw Mill): Combustion gas composition and deposition. Fuel 2013;112:572-83. doi:10.1016/j.fuel.2013.01.001.

[20] Santisteban J, Mediavilla R, López-Pamo E, Dabrio CJ, Ruiz Zapata MB, García MJG, et al. Loss on ignition: a qualitative or quantitative method for organic matter and carbonate mineral content in sediments? Journal of Paleolimnology 2004;32:287-99.

[21] Vassilev S V., Vassileva CG. Methods for Characterization of Composition of Fly Ashes from Coal-Fired Power Stations: A Critical Overview. Energy \& Fuels 2005;19:1084-98. doi:10.1021/ef049694d.

[22] Fan M, Brown RC. Comparison of the Loss-on-Ignition and Thermogravimetric Analysis Techniques in Measuring Unburned Carbon in Coal Fly Ash. Energy \& Fuels 2001;15:1414-7. doi:10.1021/ef0100496.

[23] Zhao M, Han Z, Sheng C, Wu H. Characterization of Residual Carbon in Fly Ashes from Power Plants Firing Biomass. Energy \& Fuels 2013;27:898-907. doi:10.1021/ef301715p.

[24] Wigley F. Coal mineral transformations under oxy-fuel combustion conditions Final report for BCURA Project B81 (1 January 2007 - 30 September 2009). vol. 81. 2010.

[25] Riaza J, Álvarez L, Gil MV, Pevida C, Pis JJ, Rubiera F. Ignition and NO Emissions of Coal and Biomass Blends under Different Oxy-fuel Atmospheres. Energy Procedia 2013;37:1405-12. doi:10.1016/j.egypro.2013.06.016. 
[26] Pawlak-Kruczek H, Ostrycharczyk M, Baranowski M, Czerep M, Zgóra J. Co-Firing of Biomass with Pulverised Coal in Oxygen Enriched Atmosphere. Chemical and Process Engineering 2013;34:215-26. doi:10.2478/cpe-2013-0018.

561 [27] Buhre BJP, Elliott LK, Sheng CD, Gupta RP, Wall TF. Oxy-fuel combustion technology for coal-fired power generation. Progress in Energy and Combustion Science 2005;31:283-307. doi:10.1016/j.pecs.2005.07.001.

[28] Fleig D, Andersson K, Johnsson F, Leckner B. Conversion of sulfur during pulverized oxy-coal combustion. Energy and Fuels 2011;25:647-55. doi:10.1021/ef1013242.

[29] Vassilev S V., Baxter D, Andersen LK, Vassileva CG. An overview of the composition and application of biomass ash. Part 1. Phase-mineral and chemical composition and classification. Fuel 2013;105:40-76. doi:10.1016/j.fuel.2012.09.041. 